\title{
From Judicial Transplants to Judicial Translations: Constitutional Courts in SOUTHERn Africa - A Comparative Review
}

\author{
Cosmas Emeziem *
}

\author{
Cornell University Law School \\ cce39@cornell.edu
}

\begin{abstract}
EMEZIEM, Cosmas. From Judicial Transplants to Judicial Translations: Constitutional Courts in Southern Africa - A Comparative Review. International and Comparative Law Review, 2019, vol. 19, no. 1, pp. 74-124. DOI: 10.2478/ iclr-2019-0003
\end{abstract}

Summary: The contemporary legal landscape in Southern Africa and its responsiveness to the challenges in the region can be explained in many ways. Part of the explanation has been the idea of legal transplants-which entails borrowing and adapting legal norms, and structures from different legal systems in order to resolve legal problems in the region. The end of apartheid and other rapid changes in the region-political, racial, economic and social-has directly placed the courts on the frontlines of human rights protection especially on socio-economic rights and other overarching concerns of law reform. The adoption of constitutional courts in some of the countries, and consequent judicial activist turn in the jurisprudence of courts in the region generally; has inserted the courts into the mainstream of policy deliberations. Thus, this paper claims that legal transplant per se does not explain the full reality of what is going on in the region-in terms of nomativization, transmission, adoption, and adaptation of legal ideas within the respective systems in the region. It further claims that a mesh of different understandings and approaches to legal comparison and development is more suitable as a method of studying pluralist complex systems as we see in the region. Hence, the notion of judi-

\footnotetext{
Cosmas Emeziem, Adjunct Professor of Law, Cornell University Law School; JSD (Doctor of Juridical Science) LL.M., (Master of Laws), Cornell University Law School, LL.B., (Bachelor of Laws) University of Nigeria; cce39@cornell.edu; Barrister and Solicitor of the Nigerian Supreme Court. Mr. Emeziem was a member of the 2015 Class of The Hague Academy of International Law, The Hague Netherlands. This paper was inspired by a study visit to South Africa, in the company of Professor Muna Ndulo and other law students from Cornell University Law School, in collaboration with the University of Johannesburg, South Africa during the winter break of the 2016/2017 Session. That visit included a guided tour of the Apartheid Museum, the Constitutional Court of South Africa, and adjoining apartheid time prison buildings - now transformed into a museum. It also included weeks of lectures on Law and Social Change in Southern Africa. The lectures at the University of Johannesburg also explored the South African Transitional Justice experience and its relationship with general legal development in the region. My trip was generously supported by the Graduate School Office and the Institute for African Development at Cornell University. This is an introduction of what I intend to develop into a book manuscript. Comments are welcome. Of course, any noted error in the work is absolutely mine.
} 
cial translation - the judiciary forming the membrane, purveyor and capillary of legal transmission-as an essential lens through which we can better view and understand the legal evolution in the region. Taking the institution of courts - particularly constitutional courts-and examining their jurisprudence as epitomized in some of their decisions of finality-the work seeks to begin a meaningful deliberation about the role of courts in law, social change, and policy in the region. It is divided into three major parts for ease of discourse. It is hoped that this would be a fitting exordium into the more significant meaning of legal transplant through judicial intervention in otherwise predominantly policy questions in the Southern African region.

Keywords: Legal Transplant, Constitutional Courts, Supreme Courts, Southern Africa, Judicial Translations, Constitutions, \& Comparative Law.

\section{Introduction and disambiguation of concepts}

Legal transplant has since, become a resilient approach ${ }^{1}$ to comparative legal studies. While Alan Watson popularized it, its incidents, and evolution, have increasingly become common staples used in different areas of legal studies. ${ }^{2}$ Transplant, as it is used in the subfield of comparative law, involves, the migration of legal ideas, principles, norms, and at times templates from one jurisdiction to another. Legal transplants can happen within the same legal tradition, or across different traditions. Sometimes it is an adoption. At other times, it may be an adaptation, and in more open cases, it is not just limited to the legal idea or statutory templets, but the adoption of an entire legal system. ${ }^{3}$ One indispensable

1 Interestingly for some, legal transplant is only a theory of legal studies and not a method. Others view it otherwise. In this work, I shall treat the idea of legal transplant as both a theory and methodology of comparative legal studies. This choice is informed by the fact that the bifurcation between theory and method as it affects the idea of legal transplant in comparative legal studies seems a bit superficial. It is my argument that theory essentially deals with the ideas or system of ideas used to explain or affirm the existence of something. It is the idea, the thesis and philosophy behind the idea. Method on the other hand sets out the procedure, logic or approach for establishing the existence of a particular thing. For instance, in the Aristotelian structure of reasoning, it would be difficult to separate the method of proof from the foundational theory of coherence and sequence that inebriates deductive reasoning.

2 The area of private international law, transnational law and cross-border application of legal norms amongst others are some of the areas of legal studies that have benefitted immensely from the tool of legal transplants as an instrumentality of comparative legal studies.

3 The Case of Turkey is often cited as an adoption of an entire legal system - the Swiss legal system. The adoption of the Napoleonic Code in places like Louisiana (1804) is often also cited as evidence of intercontinental transplant of law. It may also be about legal procedures like the adoption the Common Law Court procedures in recent times in many parts of Latin America. More so, the received English law in most of the Colonized communities under the British Empire is also a clear representation of the adoption of an entire legal system and superimposing it on the respective communities. In the case of these countries - the common law countries - both the common law, doctrines of equity and statutes 
aspect of it all is that, there is a diffusion of legal ideas across jurisdictions and places. ${ }^{4}$ It might transcend transnational boundaries. It may also be within the same national boundaries. The subject matter of interest in the transplant or diffusion of legal ideas may also range from private to public law. In other words, it is a masquerade that dances across the entire arena of law.

There is also a perception that, the process of the movement of legal ideas across systems is more complex than it is presently represented to be by the idea of legal transplant. Thus, simple accounts of transplants, leave a wide gap in the epistemic, and methodological values needed in the comparative law field. It leaves many things happening in the field unexplained or at best lightly examined. Hence, the idea of 'legal translations' as another way of understanding the diffusion of legal ideas, legislations and structures across jurisdiction and even within traditions. It is my thesis that a combination of these two approaches tools of analysis - will make for a better appreciation of what has happened -and continues to happen - in the Southern African region in recent years. This is as it concerns constitutional developments in general and the idea of constitutional courts in particular. This work hopes to draw attention to the increasing culture of judicial intervention in shaping policies which are flourishing in the region. It will also highlight how that connects with the overall democratic culture of the adoption of Constitutional Courts in Southern Africa and the attendant increasing juridification/judicialization ${ }^{5}$ of public policy. It is important to note that this

of general application were transplanted into the colonies. Today in places like Nigeria, Malawi, Zambia, Zimbabwe, Ghana and Sierra Leone the transplant of English common law is self-evident. Maximo Langer has examined the adoption of the plea bargain process in Latin America. It may also be the adoption of the jury system in some jurisdictions in recent times. See LANGER, Maximo, From Legal Transplants to Legal Translations: The Globalization of Plea Bargaining and the Americanization Thesis in Criminal Procedure, UCLA Research Paper Series, 2004 Vol. 45 No. 1,

4 Before Watson legal diffusion was known, but Watson made name for describing transplant as "the primary means of legal transmission from one place to another."

5 Judicialization of policy has often been defined as "the reliance on courts for addressing core moral predicaments, public policy questions, and political controversies." It has become in the recent times a consistent discourse for students of comparative politics and comparative constitutional law. A number of factors identified as predisposing societies and states from judicializing public policy concerns includes transitions justice efforts, existence of an activist constitutions court or court of finality with a disposition towards progressive construction of legislations and enactments. More so, the incapacitation of other organs of state like the legislative arm and the lack of political will by the executive in effecting needed change creates this feeling that framing the matter as a constitutional question might help place it before the courts for interpretation and finality of settlement. There is also a feeling that if kept within the realm of pure politics certain desirable. But unpopular changes required in the system will not come to be is a factor in the increasing juridification of politics. Take for instance the right of minorities - gender minorities, immigrants, religious minorities - are often highly controversial political issues. In many jurisdictions including the United States, it required intervention from the courts to unlock the space and grant equal opportunity and respect to these groups. The insulation 
work does not intend to delve into the roiling debate about potential judicial overreach arising from judicial activism. Perhaps that question, and the concerns about the limits and province of judicial review of administrative actions is a matter of an entirely different discourse which can yield rich outcome if dealt with in another piece. This paper proceeds on the premise of recognizing the capacity of courts to contribute to social change through carefully reasoned judicial review without necessarily usurping the guaranteed constitutional powers of the legislature and executive as co-equal arms of government in democratic societies. The need for this is acute in the nascent democracies that we have in the African continent.

Be that as it may, before this era, it was once permissible for Kings, Emperors and even Popes to arrogate to themselves, absolute powers of the realm. Hence the proclamation, ego sum Caesar: ego sum Imperator - "I am Caesar; I am the Emperor." ${ }^{\prime \prime}$ ' etat C' est moi - I am the State. 7 They held a 'divine mandate' which could not be subjected to regulations, or law by any other aspect of the realm. Kings were the 'makers of manners,' and their decrees were imprescriptible. Citizens lived at the pleasure of the crown, and their gratitude to the monarchy was a given. Hence, within the Kings Courts, he enjoyed absolute immunity, ${ }^{8}$ and peti-

of courts from periodic elections unlike the members of congress or executive seems to embolden courts and thus further lead to their continued intervention in many matters of policy. Of course no quite a few will view this as being beyond the brief of courts since they ordinarily seem to blur the lines of separation of powers and mutual deference between all the organs of state. See generally, BORK, R. H. Coercing Virtue: The Worldwide Rule of Judges, Toronto, Random House of Canada, 2010; CONANT, Lisa. Justice Contained: Law and Politics in the European Union, Ithaca, Cornell University Press, 2002; DOTAN, Y. and HOFNUNG, M. Legal Defeats-Political Wins: Why Do Elected Representatives Go to Court? Comparative Political Studies, 2005, Vol. 38: 75-103; EPP, Charles. The Rights Revolution: Lawyers, Activists and Supreme Courts in Comparative Perspective, Chicago, University of Chicago Press, 1998; FEELEY Malcolm. \& RUBIN, Edward. Judicial Policy Making and the Modern State, Cambridge, Cambridge University Press, 1998.

6 At the height of the Papacy particularly in the early days of modern Europe, it was not unusual to hear Popes make this observation. The Pope was for all intents and purposes seen as the Roman imperium. Hence, he had absolute authority on maters spiritual and temporal. The Pope therefore commanded a lot of moral and political force all over Europe. An example of this is perceptible in the Treaty of Tordesillas Spain-Portugal 1494. See KOSKENNIEMI, Martti. Histories of International law: Significance and Problems for a Critical Review, Paper Presented at Temple University Beasley School of Law April 12, 2013; FASSBENDER, Bardo. \& PETERS, Anne. (eds.) The Oxford Handbook of the History of International Law, Oxford, Oxford University Press, 2012.

7 Louis the XIV is noted to have made this statement in manifestation of his absolute powers. It was however not long lived as the French Revolution would later show. The absolutist monarchical perception of state and power is therefore a factor-I would argue-in the development of constitutional democracy since it was considered unaccountable.

8 "The King moreover, is not only incapable of doing wrong, but even of thinking wrong; he can never mean to do an improper thing; in him is no folly or weakness." See BLACKSTONE, William. (1723-1780), Blackstone Commentaries, bk. 1, cap. 7, William Hein \& Co., Buffalo, New York, 1992, pp 239. The background to this however, is not the absolute 
tions to the Courts of Equity were only at the discretion of the King. These 'petitions' were at best courteous prayers seeking the beneficence of the King. Such benevolence was often discharged through the minsters in the realm, who themselves held functions at the good pleasure of the Crown-in placito bene-and subject to good behavior as adjudged by the king. The above scenario of absolute obeisance, and arogation of power was seen to be problematic in many respects and indeed led to revolutions in the West and other parts of the world. In the light of the ensuing struggles and the apparent resistance by the larger societies, many of the monarchical institutions either capitulated, were deposed, or compromised in order to allow for constitutionalism. Hence, these in combination with social movements, gave rise to the establishment of basic documents or instruments of governance-the Constitution.

Thus, it is self-evident that, constitutions ${ }^{9}$ have become the most visible articulation of law in contemporary human societies. What is the constitutional law? What are its contents? How does that determine the recognition, allocation, and ordering of interests, rights, and privileges in society? How best do we organize the levers of powers in society through the constitution? What have constitutional laws got to do with public policy, human flourishing, and development? What is the purpose of the constitution and law in general? Indeed, what is the purposeless purpose' of law in general and constitutional law in particular? These are still very vibrant debates amongst scholars and policy makers. This is especially so in the global south because of the perennial issues of development and institutional fragility. ${ }^{10}$ Therefore, not minding how superficially any society may wish to answer these questions, citizens know that they are often in a constant encounter with the constitution. Of course, there is no pretense here to seek to answer all these questions within the limited frame of this paper, but to draw attention to the overarching nature of the nature and place of constitutions in democratic societies.

Equally, no matter the ideology governing the economic and social life of a community, the law is often implicated. In principle, one can argue that even for the most lay person in society, there is an appreciation of the existence of

powers or perfection of the king, rather, it encapsulates the thinking prevalent at the time that the king will use the powers embedded in him to the best interest of the people rather than in committing acts prejudicial to the society.

9 Not quite a few have argued that the global export of the idea of constitutions and the adoption of same by many countries since after the second world war is an indication of the dominant influence of the American legal system in the world today. MATTEI, Ugo. A Theory of Imperial Law: A Study of U.S. Hegemony and the Latin Resistance, 10 IND. J. Global Legal Studies vol. 10, 383, 2003; WEIGAND, Wolfgang. Americanization of Law: Reception or Convergence? in Legal Culture and the Legal Profession, FREIDMAN, Lawrence, M. \& SCHEIBER, Harry, N. (eds.) Boulder: Westview Press, 1996.

10 It equally be plausibly argued that the emergence of neo-nationalist ideologies and belligerent populism has drawn attention once more to questions of constitutionalism and their purpose as providing the indispensable guard rails of democracy. 
some general law-the 'unseen hand'; the fabled arm of the law-that affects her living and other experiences. This is even more acute in traditional societies because of legal pluralism and the fact that customary law which prevailed was largely unwritten yet held the society together. In contemporary times-and very often - this fabled hand that governs the state is perceived as the Constitution. Equally, it is not unusual to find those who think every piece of law is found in the Constitution. That is why for many states - even those ideologically indifferent to "constitutional democracy"- "constitutions" still serve the vital duty of being a totem of the rule of law. It is the symbolic source of powers, and authority in society even for despotic regimes.

Little wonder then why the lexicon "democratic dictatorships" ${ }^{11}$ has become a recurring register amongst constitutional law scholars in recent times. The study of dictatorships and their several mutations can no longer be based simply on the non-existence of constitutions or the lack of conduct of periodic elections. ${ }^{12}$ The reasons for this can be summed up in two broad terms - justification and conferral of legitimacy. The 'justificatory' and 'legitimacy conferral' roles that constitutions play in the polity are objectives that many governments cannot ignore. It is then not surprising that countries without one document which can be referred to as "the Constitution of the State," often have 'constitutional enactments' or "legislations with constitutional character. ${ }^{13}$ For many, therefore, a constitution

11 LEVINSON, Sanford. \& BALKIN, Jack, M. Democratic Dictatorship; its Dangers and Its Design, Minnesota L. Review 2010, vol. 94, 1789; ATWOOD, Roger. SAIS Review Fall 2001 vol. 21 number 2 .

12 Periodic elections and existence of constitutions were once the desiderata for measuring the democratic governance and development. Recent development suggests that this may not be exactly so. See GANDHI, Jenifer. \& LUST-OKAR, Ellen. Elections under Authoritarianism, Annual Review of Political Science, 2009, Vol. 12, 404-22.

13 This is particularly the tradition in the United Kingdom where though there is a great deal of constitutionalism, there is no specific document which can be called the Constitution of Britain. However, there are several legislations like the Magna Carter, the Judicature Acts and such other legislations which are construed by courts and other relevant policy bodies as of a constitutional character and their breach is in the nature of fundamental breaches to the constitutional character of the state. See the case regarding the parliamentary supremacy regarding Brexit. $R$ (on the application of Miller and another) (Respondents) $v$ Secretary of State for Exiting the European Union (Appellant) REFERENCE by the Attorney General for Northern Ireland - In the matter of an application by Agnew and others for Judicial Review. REFERENCE by the Court of Appeal (Northern Ireland)-In the matter of an application by Raymond McCord for Judicial Review [2017] UKSC 5, On Appeals from (2016) EWHC 2768(Admin) and [2016] NIQB 85. In that case the subject matter was the extent of ministers' power to effect changes in domestic law in the United Kingdom through exercise of their prerogative powers at the international level and the relationship between the United Kingdom government and parliament on the other hand and the developed legislature and administrations of Scotland and Wales and Northern Island on the other. The UK Supreme Court in its rule had this to say about the constitutional character of the UK "Unlike most countries, the United Kingdom does not have a constitution in the sense of a single coherent code of fundamental law which prevails over all other sources of law. 
is this document of exceptional character which is almost immutable with well set out provisions. For others, this may not be found in a particular document so to speak but in a series of documents often called constitutional enactments. It is the basic law of the society. Hence, for some, a constitution epitomizes the peoples' social contract. For others, it recognizes and constitutes the different aspects of the community and allocates resources. The ubiquity of approaches to constitutional making, and the breadth of provisions it can encompass, has made constitutions definitional in many legal systems. Indeed, often times, it is the constitution that frames the legal system, allocates powers, duties and rights. It is the legitimizing instrument of state actions.

Thus, though the idea of constitutions sometimes elicits different shades of definitions amongst scholars, there are basic ingredients often found in constitutions. It could be defined therefore that it is that which formulates the basic structure of a legal system in question. It is an organogram ${ }^{14}$ which sets out the foundations of the legal system and determines who the law maker is in the system, who interprets the law in the system; and ultimately who has the role of ensuring the daily execution of the law. Perhaps, it can be stated that to determine these functions clearly, and also forestall ambiguity; it is the constitution that sets out the different organs of the government and also articulates and defines their provenances and province of influence and control within the polity.

Today, almost all the countries of the world operate a written constitutionwith no exception in the Southern African region. ${ }^{15}$ The United Kingdom represents the latter ${ }^{16}$ - with unwritten constitution - wherein a series of documents

Our constitutional arrangements have developed over time in a pragmatic as much as in a principled way, through a combination of statutes, events, conventions, academic writings and judicial decisions. Reflecting its development and its contents, the UK constitution was described by the constitutional scholar, Professor AV Dicey, as "the most flexible polity in existence" - Introduction to the Study of the Law of the Constitution (8th ed., 1915), p 87." See page 14 of Judgement (Supra). It went on to list some of the defining enactments in the constitutional history of the country which are fundamental in the nature of constitutions. They include, the Bill of Rights 1688/9, the Act of Settlement 1701 and the Act of Union 1800 in Britain and Ireland.

14 A number of identifiable features or characteristics of constitutions will include the following: normative supremacy - it is the supreme law of the land; Judicial review of administrative and legislative actions; longevity; rigidity; regulates two major aspects - organization of government institutions and fundamental freedoms (representation and a bundle of rights); generality and abstraction. For a more elaborate examination of this idea see, MARMOR, Andrei. Are Constitutions Legitimate? University of Southern California, Studies Research Paper Series No. 06-9, 2006.

15 But even where there is a distinct document referable to as 'the constitution'-like the constitution of the United States-some significant historical papers like the declaration of Independence and the Federalist papers have significant respect amongst scholars and policy makers though they do not have the same official character accorded to constitutional enactments as we noted in the case of the UK.

16 According to James Bradley Thayer, (writing about the English Constitutions) "when one 
are designated as having constitutional importance. The constitutional orthodoxy in the region, is, therefore, the existence of written constitutions-and this is justified on many grounds-including certainty and the historical experience of the respective countries. Hence, these countries with written constitutions today lay claim to constitutional democracy, while at the same time preserving their unique characteristics. Therefore, whether for doctrinal or pragmatic political reasons, constitutions have since become perennial features of legal landscapes around the world.

Another dimension to the totemic role-surmised as justification and conferral of legitimacy on governments-of constitutions is the fact that, it is a structure for legal comparison and legal borrowing across the world. For instance, it is quite possible to compare the constitutions of states that consider themselves as federations vis-a-vis those that are considered unitary states. It is also possible to compare the constitutions of states that profess federalism with a view to highlighting the nature and extent of devolution of powers between the central governments and the federating units. In the same vein it is also significant to look at the nature of centralization or decentralization even within the provisions of unitary constitutions. There are thus, several iterations and layers through which we can explore comparative constitutionalism.

Further to this is that constitutions are also often venerated-almost like a patrimonial legacy bequeathed to the citizens one and all. Indeed, this perception has been one of the foundations of noticeable constitutional veneration in many parts of the world today. Because, citizens can actually look to the constitutions for a rescue and remedial grounds even for rights which are considered as "un-enumerated" makes it a venerable instrumentality though they may not agree with certain aspects of it. ${ }^{17}$

What this means is that, constitutional making often provides a fertile ground of legal borrowing and thus legal comparative studies. The borrowing can be in terms of norms, or institutions. It is thus a fundamental ground for judicial transplants and judicial translations. This is particularly noticeable in Africa. Decolonization efforts since 1945 and the post-cold war reforms are some of the reasons used to explain the phenomena of constitutional transplants in Africa. Indeed the transplant of constitutions in Africa began with the colonial enter-

scrutinizes the English Constitution, it is like looking at the nests of birds or at the curious and intricate work of beavers and insects; its strange contrivances seem not so much the ordered and foreseen result of human wisdom as marvelous outcome of instinct, of a singular political sense and apprehension, feeling its sure way for centuries, amid all sorts of obstacles, through and around over them, with the busy persistence of a tribe of ants". See MCNAMARA, M. Frances. 2000 Classic Legal Quotations, Rochester New York; Aqueduct Books, 1992, pp 114.

17 The 'veneration' and 'creedality' of constitutions have been explored more by Aziz Rana with respect to the United States Constitution. See RANA, Aziz. Constitutionalism and the Foundations of the Security State, 103 Cal. L. Rev. 2015, pp 335. 


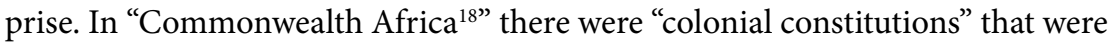
generally not autochthonous but all instruments in the hands of the British Governor General for the purpose of administering the territories. ${ }^{19} \mathrm{It}$ is also curious that though Britain has no tradition of written constitution was often in the habit of giving constitutions to these countries. It can be argued that this lack of real experience in constitutional making meant that the British driven constitutions were at best limited in terms of benefits to the communities. The climax of these colonial constitutions was the independence ordinances issued to the respective countries at Independence-often called the Lancaster model of constitutions. Of course, this has great implications for the effectivity of the transplant. Hence, it can safely be said that the transplant effect was disparate and did not guarantee a flourishing polity and democracy. Perhaps, this explains some of the post-independence challenges and effort and constitutional changes in these countries since the early days of independence.

Regarding the Southern African region, one significant element of transplant is the idea of Constitutional Courts-separate, autonomous, insulated and selfsufficient courts-imbued with the responsibility of settling constitutional controversies. This may be controversies between separate arms of government. It may also be about the rights of citizens-especially where such controversies impinge on the duties of the state to the citizens in question. This is different from the traditional idea of judicial review of an otherwise court of general judicial competence which has an equally lofty and long history. ${ }^{20}$

The adoption of this specialized constitutional courts model is often seen not only as a means of securing political legitimacy, circumscribing public powers, and guaranteeing the enjoyment of human rights; but also as an aid towards making the fundamental provisions of the constitution imprescriptible. Another perceptible justification for the adoption of constitutional courts is often the loss of confidence in courts and justice systems in general in post authoritarian societies. There is always a tendency to believe that the courts are often a major casualty of dictatorships. From Nazi Germany to Apartheid South Africa, it is not unusual to view the court system as not only a victim of authoritarian use of state powers, but also a willing collaborator with the infamous regimes. Constitutional courts, therefore, have become the new battlement around the manifest and -I would argue - latent ideals of the post-conflict or post-authoritarian soci-

18 This refers generally to the complex collection of countries in the African Continent which were formerly colonies of the United Kingdom of Great Britain and Northern Ireland.

19 NWABUEZE, B. O. Constitutional Democracy in Africa vol. 1-5, Ibadan, Nigeria, Spectrum Books, 2003.

20 The opinion of CJ Marshall in Marbury v. Madison-US (1 Cranch) 137 (1803)—comes to mind readily here. The distinction between the two being that while there is a fusion of the judicial powers both of constitutional interpretation and review of other controversies, it is clearly set out in the constitutional courts' case that it has provenance of all matters regarding constitutional controversies. 
eties. They form the new 'guiderail' of democracy-at least the ideals they profess to serve. An encapsulation of the aspirations of the new democratic order. ${ }^{21}$

Thus, the distillable reasons for the establishment of constitutional courts are many and may include the listed points above and such other purposes as "safeguarding the foundations" of the constitutional system, and "providing equilibrium between the separated powers" in the democratic society. In attempts to keep to these purposes, the constitutional courts are increasingly pronouncing on controversies that have significant policy implications-hence the increasing literature on judicial overreach and potential challenges arising from polycentricism. It is therefore currently essentially contested as to whether courts are "the ideal spaces" for policy deliberation. However, the increasing questions and concerns about judicial overreach seem to forget the vital reasons that first led to the creation of constitutional courts. ${ }^{22}$

This work in the main, takes a comparative look at the adoption of constitutional Courts in the Southern African region. ${ }^{23}$ It will give some insight about how this is contributing to the legal development and social change in the region. Perhaps, this may reveal some underlying contextual issues that have made for the ready adoption, and adaptation of the constitutional courts model in the region. Because what has happened in the region cannot just be explained as mere transplant, I have chosen to combine same with the idea of legal translations. ${ }^{24}$ Expanding the meaning of what has happened because it has undergone

21 I am aware of existing scholarship in the area contesting the limits of judicial powersparticularly in policy deliberation and implementation.

22 EPSTEIN, Lee, KNIGHT, J. \& SHVETSOVA, Olga. The Role of Constitutional Courts in the Establishment and Maintenance of Democratic Systems of Government, Law \& Society Review 35, no. 1 (2001): 117-64

23 It is important to point out that in the region South Africa, Congo and Zambia have established constitutional Courts. In the other countries, the Supreme Court sits as a constitutional court with an expanded number of judges when controversies deemed to be of constitutional flavor come before them.

24 Legal translations in comparative law has at least two important lenses through which it can be viewed. One is the idea of translating legal texts from one language to the other. This can be called the linguistic lens. This has its difficulties though philosophers and scholars have been translating legal texts like the Justinian Codes and the codes of Hammurabi for millennia. It is therefore an area of interesting and intense scholarship not just for legal scholars but for philosophers and linguists. Secondly and beyond the linguistic lens is the context of legal translation. While there may have developed clear technical rules for linguistic translation, contextualizing these translations is one that has often not been defined in several respects. It has therefore lots of embedded subjectivity. So for comparative legal scholars, understanding legal contexts is critical element in studying the processes of legal movement from one system or jurisdiction to another. Courts and particularly constitutional courts therefore do not just look at legal texts or translate norms from one system to another, it is my argument that they also engage in some level of translation - attempting as it is to situate the norm, principle or legal template within their legal culture or legal environment. In doing this they often bring to bear their own experiences and sometime subjective inclinations in the transplant and translation of these norms. For more on this see 
apparent mutation in the process of legal movement. This is to my mind a better analytical approach to the study of the phenomenon of constitutional courts in the region.

Structurally, the essay is divided into five unequal parts. Part 1 introduces and explores the general concepts employed in the work and other related tools of analysis. Part 2 gives a general highlight of the adoption of constitutional courts around the different regions of the world. Part 3 gives emphasis to the constitutional development history of the Southern African region. This lunches the work squarely into the analysis of the constitutional courts in the region using South Africa, Zambia, for illustrative comparison. At this point, an attempt will be made to look at the establishment, jurisdictional competence, personnel and administrative structures of the courts as the basis of analysis.

Equally some significant issues related to access to justice and procedure will be highlighted. It will then juxtapose these courts with their functional equivalents in the region-Namibia, and Botswana. Part 5 will take a look at some important judgements which these constitutional courts have delivered in recent times. I consider these cases important because, they have shifted not only the jurisprudence of the subject matters they dealt with but significantly influenced public policy and social change. This is aimed at showcasing these strategic judicial interventions in the society and policy-particularly in the evolution of fundamental freedoms. It shall then draw some preliminary conclusions and make recommendations for future legal research and development. But first, an articulation and disambiguation of basic concepts.

The idea of law is arguably one of the most complex creations of the human mind. Constitutional law epitomizes laws extensions and overarching web on the society. Its existence in one form or another from one society to another has come to be accepted as a given. This has given rise to several ways of looking at constitutional foundations - source, duty/function, articulation and interpretation in human society. While legal origins are an undying preoccupation of legal anthropologists and jurisprudence, ${ }^{25}$ legal interpretation has also gradually

HENDRY, Jennifer. Comparative Law and the (Im) possibility of Legal Translation, in Comparative Law: Engaging Translation (GLANERT, S. ed., 2014; FRANKENBERG, Gunter. Constitutional Transfer: The IKEA Theory Revisited I. Con (2010), Vol. 8 No 3, 563-579.

25 A great deal has been written on this subject. Hence the literature is rich and vast. A small introductory list would include, AUSTIN, John. In Austin: The Province of Jurisprudence Determined, edited by Wilfrid E. Rumble, i-iv. Cambridge Texts in the History of Political Thought. Cambridge: Cambridge University Press, 1995; HART, H. L. A. The Concept of Law. Oxford: Oxford University Press, 1994; HOLMES, Oliver, Wendell. The Common Law, Boston, Little Brown \& Co., 1881; CARDOZO, Benjamin. The Nature of the Judicial Process, New Haven, Yale University Press 1921; RAZ, Joseph. The Concept of a Legal System: An Introduction to the Theory of a Legal System (2nd ed.) Oxford, Clarendon Press, 1980; KELSEN, Hans. Pure Theory of Law, California, University of California Press Berkeley, 1967; FINNIS, John. Natural Law and Natural Rights, Oxford, Clarendon Press, 1980; WEINREB, Lloyd. Natural Law and Justice, Cambridge; Harvard University Press, 1987. 
assumed a critical position in the development of constitutional law as we know it today. One incident of this is the development of different schools of jurisprudence and their respective articulations of law-and by extension constitutional law-regarding these far-reaching foundational issues of source, content, function, obligation, and the like. Hence the various definitions of law.

What is distillable from the field is that, it is no longer possible to limit the understandings of law - constitutional law in this case-to the legislative authority. ${ }^{26}$ Ordinances of the law giver-especially on constitutional provisions which are often general - without more, leaves the nature, function and content of constitutional law provisions highly impoverished. Legal interpretations have further adjusted the prime place of legislatures as the exclusive source of law and its functions. Administrative bodies, tribunals, and courts ${ }^{27}$ have also added to the complexities of application of constitutional law and its purpose in societyespecially so in pluralist societies. Hence, the giver of law-be it prince, queen, chief or parliament-has gradually receded into the background as not the best interpreter of law. ${ }^{28}$

The axiom that the concentration of the power of law making, interpretation and execution in one institution or person is the finest definition of unconstitutionality and authoritarianism has since become embedded in the respective legal traditions. The balance of power - the capacity of one form of power to check the other - has become the desideratum of separation of powers in most modern constitutions. ${ }^{29}$ These have all become indicators of rule of law and constitutional democracy.

26 The pivot to this disposition - at least in the common law legal tradition-was greatly enhanced by the American School of realism. When Oliver Wendell Holmes in wrote his essay regarding the Path of Law and the Common and Surmised that the Prophesies of what the courts will do in fact and nothing more pretentious is what he meant by the law, he set off strongly a movement whose influence has continued to resonate in law since then. The Sociological school by Roscoe Pound also gave strong bent to a more social look on law. Today empirical studies of law have become well known and deeply accepted a major contributor to the body of legal knowledge and an indispensable tool of legal studies. The critical theorists also have a tendency towards a more fundamental questioning of law and its role in society. These are all different ways of looking at law and what it does in society which we can no longer take without a critical review.

27 DWORKIN, Ronald. "Law as Interpretation." Critical Inquiry 9, no. 1. 179-200 (1982): http://www.jstor.org/stable/1343279.

28 Even in the law tradition where legislative enactments are accorded a creedal reverence, the opinion of publicists is critical to the understanding of law. Hence the writings of say Cicero or commentaries on the Justinian code are often considered canonical works in the understanding and application of principles of Roman law. This tradition permeates the development of the civil law tradition even today.

29 It is acknowledged that the law in books may not be a true representation of the law in action hence, existence of separation of powers in constitutions around the world may not be a show of respect for rule of law nor does it translate to fundamental freedoms. What this explains however is our earlier assertion that even those that pay lip service to rule of 
What this creates is sometimes akin to the "Speluncean experience-various construction of a given set of facts and constitutional provisions by different interpreters." ${ }^{\text {"30 }}$ This has led to an increased role of courts, and the possibility of shades of interpretations with a high potency of reordering the content, functions and indeed sources of norms of constitutional laws in society.

\section{1 'Laws Empire' and Methods of Comparative Legal Studies}

"It matters how judges decide cases. It matters most to people unlucky or litigious or saintly enough to find themselves in court ... the difference between dignity and ruin may turn on a single argument that might not have struck another judge forcefully, or even the same judge on another day. People often stand to gain or lose more by one judges' nod more than they could by any general act of congress or parliament." 31

law and constitutional democracy still need the legitimacy conferral capacity of the constitutions hence the adoption of the provisions so as to create a semblance of it.

30 Recall that in a seminal essay, titled The Case of the Speluncean Explorers, Harvard Law Review Vol. 62, No. 4, February (1949), Lon Fuller, drawing inspiration from the fact pattern in Regina v. Dudley and Stephens 14 Q.B.D 273 (Queen's Bench Division 1884) tried to highlight the moral questions that the case raised. In that case, Dudley and Stephens along with Brooks and Parker (victim) were cast away at Sea for weeks without food and water except for some turnips and a turtle. After twenty days, Dudley and Stephens proposed one person sacrifice himself in order to save the rest. Brooks will not have that. $\mathrm{He}$ dissented while Dudley and Stephens decided to kill parker since he was the weakest and the youngest. This they did on the $25^{\text {th }}$ of July 1884 since they saw no rescue in sight. Four days later they were rescued by another vessel and Dudley and Stephens were charged with murder. The issue for determination then revolved around the point whether an innocent person can be killed in order to save one's life? This was held to be inappropriate and the accused persons were convicted of murder. Drawing therefore from this situation, Fuller wrote his piece. Though it concentrated on the moral questions raised by the case, it was also significant in the way that the opinion of the respective fictional judges differed. Thus, though the law remained the same in all respects - in terms of the framing and letters, its interpretation could differ, and all such interpretations may actually appear plausible prima facie. This puts courts and publicists - depending on the legal tradition in issue - at the center of legal development and legal interpretation.

31 DWORKIN, Ronald. Law's Empire, Cambridge, Massachusetts; Harvard University Press, 1986 pp. 2; Brown vs Board of Education of Topeka, 347 U.S. 483 (1954); The UK case on Brexit $-R$ (on the application of Miller and another) (Respondents) $v$ Secretary of State for Exiting the European Union (Appellant) [2017] UKSC 5 [2016] EWHC 2768 (Admin) and [2016] NIQB 85; the South African Constitutional Court Decision on Executive Corruption show the extent to which courts can influence the trajectory of nations and communities by rendering judgements that have immediate and unquantifiable impact on public policy. Dworkin expresses the view that legal reasoning is an exercise in 'constructive interpretation'. He points out that "we live in and by law. It makes us what we are; citizens and employees and doctors and spouses and people who own things. It is sword, shield and menace: we insist on our wage, or refuse to pay our rent, or are forced to forfeit penalties, or are closed up in jail, all in the name of what our abstract and ethereal sovereign, the law has decreed. And we argue about what it has decreed even when the books are supposed to record its commands and directions are silent; we act then as if law had muttered its doom, 
Since the basic duty of courts is to determine controversies in society, and it is important to understand the impact of these decisions on the larger polity. Because constitutions determine the provinces of particular organs of state, ${ }^{32}$ and regulate the use of state powers, constitutions have since assumed a near imperial position. A ground of veneration, if you like. This is particularly so in constitutional democracies.

Essentially, constitutions have emerged as the stuff of societal ordering. The instrumentality with which social relations are articulated and organized. 'Laws Empire' as it has been referred to by some writers is therefore made manifest in the constitution as the connecting ligament of the different branches of law that rules the society. Constitutions thus envision, arrange, organize, allocate and prescribe the provinces of relationships in society. In a way every law or law-making power is often traceable to the constitution. Otherwise, such laws if not expressly illegal are considered unconstitutional and thus null, void and of no consequence to the extent of its inconsistency. Stretching it further, one can argue plausibly that today the entire web of law is traceable-albeit conceptually-to the idea of constitutions. One paradigmatic development from the idea of constitutionalism is the idea of constitutional courts. ${ }^{33}$ Their emergence and transplant has been seen around the world with some significant level of success. In southern Africa, it has also been adopted in many of the states particularly following the wave of democratization in the aftermath of the cold war.

The emergence of constitutional courts is also a clear testimony to the felt necessity for a more effective enforcement of democratic tenets, since the later part of the 20th century. Many often see the phenomenon as an aspect of what has been referred to as the judicialization of politics. ${ }^{34}$ But first of, the idea of diffusion of laws in general and the comparative methodologies-legal transplant, legal translations and functional comparison.

too low to be heard, distinctly. We are subjects of Laws Empire, liegemen to its methods and ideals, bound in spirit while we debate what we must therefore do" - ibid page 1.

32 Because a constitution is not the creation of the state. "It is a not an act of government, but of a people constituting a government; and government without a constitution, is power without a right" - PAINE, Thomas. Rights of Man, London, Watts \& Co., 1906 pt. 2, chapter 4.

33 Over 50 (fifty) Countries today have Constitutional Courts. Many of them are of the civil law tradition but since the end of the cold war and consequent transitional processes around the globe constitutional courts have become a recurring institutional framework to safeguard the new/emergent democracies.

34 Judicialization of politics is reckoned to mean "the reliance on courts and judicial means for addressing core moral predicaments, public policy questions and political controversies." See HIRSCHL, Ran. The Judicialization of Mega Politics and the Rise of Political Courts, Annual review of Political Science, 2008. 


\subsection{Diffusion of Laws in General}

Legal diffusion is a general term used to describe the entire collection of processes and means by which laws move from place to place. It embraces both organized movement of laws, legal norms and concepts and also the not so organized processed. In other words it is a mesh containing such labels regarding the movement of law which includes reception, circulation, transmigration, transposition, spread, expansion, transfer, exports, imports, and imposition. ${ }^{35}$ Hence inclusive in the broad idea of legal diffusion is the emergence of what one will take the liberty to call dominant methodologies for the comparative studies-legal transplant and functionalism.

I say they are dominant because they have been instrumental in shaping the discourse in the field the greater part of the $20^{\text {th }}$ century and globalization in the $21^{\text {st }}$ century and post-cold war incidents of reforms in the global south and in Eastern Europe has further heightened their elevated place within the pantheon of legal comparative studies. Within the equally broad platform of legal transplants and legal functionalism as methodologies of comparative studies lies the other iterations of what has come to be known as translations. Hence a discourse of transplantation today without a commensurate interrogation of legal translations as in the technical way it is used in comparative legal studies is one that would be grossly inadequate. Hence, the attempt here to highlight the intersection between legal transplants, legal translations and functionalism. This is significant in that it is important in understanding the legal developments around constitutional courts in southern Africa and how they have become the defining bacons of the legal landscape in the region.

\subsection{Legal Transplants and Legal Translations}

"In seeking inspiration for change, it is perhaps natural for lawyers to go browsing in a foreign law boutique."36 Legal transplantation is a core idea in the field of

35 Even at this, the list is not exhaustive.

36 DAMASKA, M. The Uncertain Fate of Evidentiary Transplants; Anglo-American and Continental Experiment, American Journal of Comparative Law, vol. 45 pp. 839, 852 (1997). Damaska has a more cautious view of the idea of legal transplant hence his observations in the paper cited thus "Those contemplating to combine common law and civil law approaches to fact-finding should be especially sensitive to the potential costs of normative shortcuts to procedural reform; institutional differences between the two Western legal families capable of affecting the fact-finding style are quite considerable. In criminal procedure, a few good lessons have already been learned about problems that arise when factfinding arrangements from one family are incorporated into the institutional milieu of the other. Here experience has shown how easily an imported evidentiary doctrine, or practice, alters its character in interaction with the new environment. Even textually identical rules acquire different consequences in the changed institutional setting. The music of the law changes, so to speak, when the musical instruments and the players are no longer the same" page 840 (supra) Damaska's view though founded more on the procedural aspects of law made a strong case for looking beyond the normative aspects of law in the process of 
comparative legal studies. Perhaps one could argue that it has dominated a large part of the discourse in comparative legal studies. It generally involves the various means of transmission, transfer and movement of legal principles, norms, and legislations and sometimes an entire legal architecture from one jurisdiction to another. The complexities of it are not what is essential to the scholars who enunciate the idea of legal transplant but the fact that it occurs, and it is the primary means of legal change or legal development around the world. The major proponent of the idea of legal transplant is Allan Watson. ${ }^{37}$

Since Watson proposition, legal transplant has become the point of departure for so much literature in the field. A core principle in all his enunciation of the idea is that there is a diffusion of legal ideas and sometimes an entire legal system or aspects of it may be adopted, adapted and transplanted from one legal environment into another. This he argues is the primary means of legal development or movement of legal ideas. Thus, it may involve a mix of concepts, different approaches and methodologies. One 'common core ${ }^{38}$ however, is that there is a diffusion of legal ideas from one place to another. Thusly, if one was to offer a general explanation of Watson's theory of legal transplant, it can be asserted that the theory can be boiled down into three fundamental propositions.

First, Watson asserts that, law is generally out of context much of the time and perhaps even most of the time. This he explains is due to the fact that legislations lie in the statute books for years without being in consonance with the developments in society, yet society tolerates such laws. The rapid changes in society notwithstanding law, remains the same and even when amended, only shifts the needle just enough not to violate the social equilibrium. Thus, it often falls short of legitimate expectations-in line with the changes in society. ${ }^{39}$ Wat-

transplant and truly reflect the possibilities that lie in the fact that laws and rules are being moved from one environment where the institutions, operators and the new environment might be different and indeed become determinant in the way it received or otherwise utilized in the system. The cautious of view of legal transplants is well founded but the incidents of legal transplants are still with us in all aspects of law. They are, however, very prominent and visible in the area of constitutional law and we shall see in the following parts of this work.

37 WATSON, Alan. Legal Transplants, An Approach to Comparative Law, Athens, University of Georgia Press, 1993.

38 I use the word common core in the ordinary English language sense. One must not confuse this with the common core movement in comparative legal studies aimed at unification or such other goals as championed by the eminent jurist Rudolf B Schlesinger. Common core has achieved a lot in the field of comparative law. Particularly significant is the contribution it has made to legal harmonization in Europe. What one cannot ignore however, is the criticism regarding questions of legal hegemony surrounding the movement. However, common core is still much useful in understanding the historical evolution of some multilateral legal templates governing common market. There is also still now an attempt at legal harmonization on issues of trade and transnational transactions, and business.

39 See generally, WATSON, Alan. Society and Legal Change (2ed.) Philadelphia, University of Temple Press, 2001; WISE, Edward M. "The Transplant of Legal Patterns, American Journal 
son further argued ${ }^{40}$ that though society has the capacity to make laws, changes in society both politically and economically are not often immediately followed by changes in law. The law he argued often remains the same or at best changes slightly. This view was considered radical at the time since it challenged what had almost been taken as the holy grail of comparative law -the social theory of law. It challenged the axiomatic claims of the sociological school that the changes in society and law society are inexorably bound together since changes in law are often the about the 'felt needs' of the society.

However, this was not in the least a new debate. Friedman in 1959 had written thus: "the controversy between those who believe that law should essentially follow, not lead, and that it should do so slowly, in response to clearly formulated social sentiment - those who believe that the law should be a determined agent in the creation of new norms, is one of the recurrent themes of the history of legal thought. It is tellingly illustrated by the conflicting approaches of Savigny and Bentham. ${ }^{41}$

Next, Watson proposed that when the law actually changes, it does so largely through legal borrowing-legal transplantation being the most outstanding way of legal development or change. In the end, he surmised by saying that legal transplantations are socially easy and that legal ideas can travel from one place to another showing a lot of capacity to survive and resilience. This he sought to support by tracing the spread of Roman law and its principles throughout Europe. By tracing the Roman law foundations of some of the principles of contract and property ownership as we know it today - both within the civil and common law tradition - amongst others, he illustrated their unique capacity to survive and thrive in the transplant communities for generations. The historicity evident in Watson's work evidences his understanding of Roman law and unique position which the Scottish legal system gave him in that endeavor. The unique position being that it seems to be that the Scottish system is a frontier system straddling the intersection of the civil and common law tradition. Thus, like the waters of an estuary frequently receives the inflow of materials from both sides of the legal traditions and in the process retains some aspects, which though adapted to serve local needs, are immensely beneficial to our understanding the idea of legal transplantation.

However, and as one would expect, Watson was hugely critiqued by scholars. Legrand as we mentioned earlier viewed the theory of legal transplant as an impossibility. Hence, for him the search for similarities between legal systems misses the point about differences and equally adds nothing to the existing body of knowledge. Above all, finding similarities does not help explain the legal plu-

of Comparative Law, Vol. 38, 1990.

40 WATSON, Alan. Law out of Context, Athens, University of Georgia Press, 2000.

41 WOLFGANG, Freidman. Law in a Changing Society, Los Angeles, University of California Press, 1959. 
ralism which exists around the world. The cultural embeddedness of legal rules and norms seems not to have received the full warmth of Watson's intellectual rigor. Thus legal rules are not transplantable in that they are customized or purposefully created for a given society. They therefore naturally change or mutate even if attempts were to be made to transplant them. He surmised by noting that transplants remove laws from their cultural milieu, and thus they ultimately become dysfunctional. Legrand's view is critical to the extent that it draws attention to the need to understand and understudy the make-up of the recipient society as a first step towards an effective and functional transplant. One does not share the views as expressed by Legrand that transplants are not possible. It is argued that legal transplants do take place and a good number of times not in the original forms in which the laws were found. The adjustments and maladjustments of these transplants in the new legal environment is an entirely different matter. It is still debatable whether transplant is good or not but this does not detract from the fact that it takes place across traditions and even within the same tradition.

Interestingly, the nature of comparative law is that it also refuses to focus on law qua law, as the only means to the proper understanding of law. ${ }^{42}$ It also borrows hermeneutic tools-across the social sciences and humanities-to infuse new life to or better sharpen its existing tools of comparative studies. The borrowing of tools from the other disciplines especially the social sciences has a long history. ${ }^{43}$

Thus in response to some of the criticisms of legal transplant some scholars have advanced the argument that comparative law should seek a new metaphor for the movement of legal ideas between different jurisdictions and legal traditions. One of such alternate metaphor is the idea of legal translation. Specifically, the need to look at this alternate idea of legal transplant is the fact that the meta-

42 Merryman had once accused lawyers of being parochial and comparative law is an attempt to cure them of that malaise. Though this was said in the context of studying one branch of law or being immersed in one jurisdiction or legal tradition, it has become continually apparent in contemporary times that the tools of social sciences like empirical research methodology are relevant to understanding the role of law in society. See SIEMS, Mathias. Comparative Law. In Comparative Law, $2^{\text {nd }}$ ed., Law in Context. Cambridge: Cambridge University Press, 2018.

43 Dean Roscoe Pound and the Sociological School of Jurisprudence helped to popularize the idea of the social sciences offering broader analytical tools to the law than it would have had if it remained strictly within the "province of jurisprudence" as canvassed by Austin and his disciples. Critical legal theory has taken that a notch higher by drawing attention to how existing tools of law can become an albatross to legal reform. Hence the need not to take law as given but to interrogate its contents and impact in society. Of course no legal theory is absolutely unassailable, but they offer insights into the overarching aspects of laws interaction with human society. Increasingly, the ideas of translation and interpretation traceable to philosophy and comparative literature have found their ways into the lexicon and collection of analytical tools available to comparative law. 
phor of legal transplant has a problem. The chief problem being "that it conveys the notion that legal ideas and institutions can simply be 'cut and pasted' across legal systems. Thus, this metaphor fails to account for the transformation that legal ideas and institutions may undergo in the process of their transfer between legal systems." ${ }^{44}$

This proposition speaks to the understanding of legal ideas, concepts and norms even as we "trans" (move) them from one tradition or jurisdiction to the other either by way of legal transplant or otherwise. This idea of translation is therefore of immense heuristic value because if a legal structure or institution is not well understood then it becomes difficult how but is moved across jurisdictions and traditions. Indicative of this, is the notion that interpretation is a key aspect of the proper understanding and transmission of legal ideas. Even institutions, when they are adapted and moved from one tradition to the other are often a translation of the normative and fundamental conceptualizations of the legal infrastructure. This is often done bearing in mind the purpose the new legal idea or structure that it is hoped to serve in the recipient jurisdiction.

Thus, translation is seen as a more sophisticated way of interpreting and conveying what is happening in the field. It is therefore the view here that a combination of these approaches is a better approach of understanding and meaningfully studying the phenomena of constitutional courts in the Southern African region - and how that has continued to play a role in the legal development of the countries in the region.

\subsection{Functional Comparison-The Better Approach?}

Arguably, the field of comparative law is fraught with sometimes recondite arguments about the place of particular theories, concepts and approaches to comparative legal studies. This is not surprising because the theoretical foundations of this subfield are always contested grounds of legal scholarship. Even its very nature as a subfield as opposed to just a method of legal studies has continued to generate debates. Hence, it is hardly surprising that, certain scholars in the field have construed that there is a better approach to comparative legal studies. This is called the functional approach-functionalism.

Functionalism, ${ }^{45}$ is another means of understanding the duty or goal of any law and therefore better explains the value accruable from any legal transplant.

44 This is the thesis of legal translation as proposed by Maximo Langer (supra) note 3.

45 Functionalism is a term that reoccurs frequently in many fields of learning. Different understandings of it therefore exist. For instance we see structural functionalism in the social sciences. The field of comparative law also relies on functionalism as a major aspect of its overarching methodology and epistemology. In some sense it deals with the operative aspect of law in society-law in action as opposed to law in the books. It has also more diverse meaning in jurisprudence which principally emphasizes the effectiveness of law in society as opposed to principles and standards as may be found in the statutes. 
Transplantation is not an end but a means of achieving some societal legal objectives. ${ }^{46}$ There are needs, purposes or ends for which legal transplants are made. One means of studying the extent of the fulfillment of these goals is through the method of functional comparison. It is a means of understanding what to compare else the study of transplants may become a metaphysical exercise disconnected from the true ends of a given legal instrumentality.

The functionality is also linked to the source and normative legitimacy of given rules of law or given legal mechanisms. Hence the need to ensure that it is decontextualized or examined from an epistemological, historical and social

However, the interest we have regarding functionalism in this work is to the narrow stipulations which it has in comparative law. For some writers, functionalism in itself is not a method but rather a principle of the comparative method of legal studies. Others like Ralf Michaels however have the sentiment that functionalism is a core methodology of comparative legal studies. This sentiment is in line with that expressed by Zweigert and Kotz. One notable thing however is that it is thesis of functional comparative methodology that the better approach to understanding and comparing legal systems or aspects of it is best via examination of the functions which the perform in the different systems. Thus laws that perform similar functions are comparable. See generally, KAHN-FREUND, O. Comparative Law as an Academic Subject, Oxford, Clarendon Press, 1965; MARKESINIS, Basil, S. Foreign Law and Comparative Methodology: A Subject and a Thesis, Oxford, Hart Publishing, 1997; ZWEIGERT, K. Z. \& KOTZ, H. An Introduction to Comparative Law (3rd ed.) 1998; MERRYMAN, J. H. The Loneliness of the Comparative Lawyer, Boston: Kluwer Law International 1999; GRAZIADEI, Michele. The Functionalist Heritage, In Comparative Legal Studies: Traditions and Transitions, edited by LEGRAND Pierre and MUNDAY Roderick, 100-128. Cambridge: Cambridge University Press, 2003. In this paper Graziadei notes that "functionalism is a broad term. In the field of comparative law, it denoted at least two distinct, yet related currents of thought. The first is linked to the methodological concerns. In this context an analysis of the functionalist heritage involves an assessment of the strengths and weaknesses of the functionalist method which is one of the best-known working tools in comparative legal studies. The second understanding of functionalism evokes the idea that law responds to society's needs - a view which some comparatists find more attractive than others in order to explain differences and similarities between the world's legal systems;" SAMUEL, Geoffrey. Epistemology and Methodology of Comparative Law: Contributions from the Sciences, 35-78, In Epistemology and Methodology of Comparative Law edited by HOECKE, M. Van. Oxford, Hart Publishing, 2004.

46 Some of the reasons often adduced for legal transplants includes creating uniformity and universalism. This helps in producing common rules of trade, business, political culture, human rights and other forms of transnational engagements. It is equally epistemological in that they help in creating common cores across jurisdictions and systems. Legal development is another often-quoted reason for legal transplants - the enduring purpose of understanding legal transplants being to appreciate the causal connection between a rule of law and its origins. Thus the epistemological question of what the law is, is only properly understood and answered via the historical question: how did the law come about? Again, because of the complexity inherent in creating an entirely new system, one would argue, that it is easier for jurists to borrow from an existing structure or system of law that reinvest the wheel. See further SAPAROVA, A. A. Legal Transplants: Nature and Structure of Content, 10 Journal of. Comparative Law, vol. 93, 2015. 
distance. ${ }^{47}$ According to Ralf Michaels, "functional comparative (studies) focuses not on rules but on their effects, not doctrinal structures and arguments, but events. Consequently, its objects are often judicial decisions as reactions to real life situations, and legal systems are compared with regard to their answers to similar situations."48 As noted by Gunter Frankenberg "comparative law is somewhat like travelling. The Traveler and the comparatist are invited to break away from daily routines to meet the unexpected and perhaps to get to know the unknown." ${ }^{49}$ In that endeavor he further opines, and rightly so that functionalist method guarantees objectivity and restraint. ${ }^{50}$ The elucidation of the functionalist method here puts us in a position to relate to the ideas we shall be discussing in the work. This is with particular reference to the idea of functional equivalents of the constitutional courts. It is suggested that since not all the countries of the southern African region have constitutional courts, it wise to look at their apex courts which are imbued with the constitutional capacity for judicial review of administrative and legislative acts which have constitutional flavor. This explains why it is important to look beyond institutional designs in order to see how different communities are responding to critical constitutional problems and their consequent implications for law and social change.

47 If one may further argue the organization of a society being an interlinkage of several aspects of society which ultimately forms a whole, the proper appreciation of the law and mechanisms of rule of law in society is to be examined as an organic whole - a system tied at several ends. This is incredibly so in post authoritarian societies because to sustain absolute hold on power, nothing is ever left to chance or uncensored evolution of human interaction in society. Indeed ideologies and worldviews are consciously choreographed into the minds of the populace. For those citizens who may prove stubborn these are seared into their minds through all forms of state abuse including torture and incarceration. For others who may seem impervious, it is not unusual to find that the state crystalizes them out from the society and gets rid of them through several measures including disappearances and executions.

48 RALF, Michaels The Functional Method of Comparative Law, Duke Law School Faculty Scholarship Series 2005, Paper 26. http://lsr.nellco.org/duke_fs/26. In that essay, he began by noting that "the functional method has become both the mantra and the bête noire of contemporary comparative law. For its proponents, it is the most fruitful, perhaps the only method of comparative law. For its opponents, it stands for everything that is bad about mainstream comparative law". Page 1.

49 FRANKENBERG, Gunter Critical Comparisons: Rethinking Comparative Law, Harvard International Law Journal vol. 26, 1985.

50 Zweigert and Kotz have further expressed the same view about functionalist comparison when the noted that function is the start point and basis of all comparative law. It is the beginning and end of comparative law. To them this means that "the solutions (that) we find in the different jurisdictions must be cut loose from their conceptual context and stripped of their national doctrinal overtones so that they may be seen in the light of their function, as an attempt to satisfy a particular legal need". See ZWEIGERT, K. \& KOTZ, H. An Introduction to Comparative Law, 1-10, Oxford: Clarendon Press, New York; Oxford University Press, 1998. 


\subsection{Why Courts?}

The work focuses on courts because they are like the public arena of contestations in democratic societies. The quintessential public sphere for debates about the legal and social transformation of the society. Courts also demonstrate the depth and extensions of the law. Much as courts may not be like the amphitheater where gladiators fight for laurels, sometimes it seems very much like it, in many respects. It is a space of struggle to assert the freedoms guaranteed in the law. It is a space wherein the waters of freedom are unlocked and channeled to flow in particular pathways. Since the evolution of constitutional democracy they have further assumed a more prominent role. Thus, they are sometimes and perceived as spaces of resistance-a space for challenging domination and seeking a share in the overall promises of the constitution. In transitional societies, this is very significant because of the legitimizing role that courts play in the ordering of powers and domination in society. Often at the height of authoritarian violence, the courts are used to rationalize; either the violence or the accumulation of powers. Hence, given the conservative structures of the polity, the credibility authoritarian governments fervently hunger for in the sustenance of their domination, and violations of the rights of citizens is reinforced through the instrumentality of courts. Authoritarian powers are at their best when courts are silent or when such courts find refuge under the fig leaf of judicial neutrality or avoidance of 'political questions.'

I also argue that 'judicial deliberations' are also 'democratic deliberations.' It is in a way a dialogue which can be viewed from three positions of interlocution. First, it deliberates in such a way as to put aside whatever shadows that might have fallen on a piece of legislation-especially constitutional provisions-over time and illumine its contents. It wrestles with the temporal nature of law via-ávis social questions while keeping a firm view of the overarching goal of objective interpretation. To interpret and thus unfold its truest meaning so as to give life to the letters and spirit of the constitution-becomes indispensable. Indeed, one of the most significant cannons in judicial review is finding the original meaning of the text. The other limb of interlocution is to see how the law responds to contemporary challenges. Perhaps, a challenge that was not even contemplated in the beginning. When courts are faced with those hard cases where the legislature might have spoken ambiguously, this work of seeking out what is to be done becomes a keenly contested work - particularly regarding the propriety or otherwise of the judicial intervention as opposed to legislative amendment. Even, then, we are not done yet with the interlocution, since courts also have the task of interpreting the law to give access to the larger interest of justice and uphold the aspirations of the constitution. Such aspirations which are often captured in such words as equality, due process, dignity and the like are often the source of some of the most extensive discourse in legal jurisprudence. Bearing that in mind, it 
is telling that the intense deliberation that takes place in courts- especially over constitutional matters - is often under represented.

Moreover, while judicial deliberation might seem removed from the daily nature of ordinary citizens' deliberations in and about the public sphere, it often generates a welter of chatters within the public sphere especially when it turns on some critical concerns in the society in that moment. While there are potential possibilities of limiting and whittling down popular democratic deliberation, I argue that the often-missed aspect is the resonance of deliberations, dialogues, debates and conversations around important questions of law in the larger society once it is a subject matter of constitutional litigation/judicial review. Therefore, judicial deliberations generate the basic raw materials for communicative acts in the large public sphere of citizens. In essence, it is not necessarily so that judicial interventions close the spaces for wider consultation, and representative debate by law makers, they may actually trigger it off and force the other arms of government to act in the best interest of the state. They can also be the successful endpoint of social movements.

Hence, while the brilliance of the written constitution may cast a great light on the foundations of society-the space for its proper brewing and consumption seems to swing sometimes towards the courts. It seems to me then that what the courts do are essential and need not be considered as prima facie and attempt to usurp the powers of the other arms of government. Where the courts fail in this duty - of keeping watch to see that constitutional provisions are animated to guarantee the progressive development of society, tyranny is strengthened, and the courts become not only a spaces of undue veneration; but the heart of the struggle for the recognition, respect, and fulfilment of fundamental freedoms.

Examining this idea recently a scholar had this to say; "law is the pre-eminent discourse of domination. Its institutional structure and normative content reflect the existing configuration of force relations within society. Law conserves and sustains the founding configuration by codifying it into laws and institutions. In essence, law performatively condenses its violence in inauguration and preservation into legal norms and transforms them into normative relations. As the symbolic personification of the majesty of law, and order, the court is law's foremost geography of power whose primary function is to secure the existing distribution of power within the body politic... by distinguishing itself from a norm giver and disguising as a neutral norm interpreter, the court conceals the violence of the system and dispels the shock of daily occurrences." 51

Bearing this in mind, it is therefore clear that a transformative society must also be hinged on a transformative judiciary. Hence, it is true that one of the major struggles in rapidly changing societies is the need to rebalance the scales

51 ALLO, Awol. (ed.) The Courtroom as a Space of Resistance: Reflections on the Legacy of the Rivonia Trial, Glasgow, Ashgate Publishing, 2015. 
of justice such that the scale of power is neither overly concentrated in one group, or segment of society; and the assurance that the courts are not captured as a tool of the legitimization of dominance. The constitutional courts in Southern Africa, I would argue are informed by this overarching interest of society. We shall now turn to the question of constitutional judicial review and constitutional courts.

\section{Approaches to Constitutional Judicial Review \& the Idea of Constituti- onal Courts}

The place of courts as the interpreter of constitutions and the general powers of both government and citizens within a polity has since become a settled norm in constitutional democracies. It is therefore possible to argue today that the democratic health of any nation that lays claim to democracy and rule of law can be evaluated based on a careful examination of the judgement of the courts. Thus, indicators like access to courts, independence of the judiciary, method of appointment of judges and transparency of proceedings have all become the irreducible minimum when considering these overarching questions. Globally too, the judicial organ has consistently continued to acquire a strong voice in determining the trajectory of justice in jurisdictions across the world..$^{52}$

However the independence of the judiciary and it powers to construe, expound and interpret the powers, rights and privileges of entities within a polity was not always a given. Many struggles for the articulation of these powers and their protection have been wrought in history and even now courts are still often on the forefront of attempts accumulate powers. This can be seen in the politics of judicial appointments around the world. ${ }^{53}$ However, at the turn of the $19^{\text {th }}$ century, CJ Marshall put it beyond pale that: "It is emphatically the province and duty of the judicial department to say what law is. Those who apply the rule to particular cases, must of necessity expound and interpret that rule. If two laws conflict with each other, the courts must decide on the operation of each." ${ }^{4}$ Since, this epic decision, the expansion and espousing of judicial review has become a perennial feature of modern constitutions.

52 The Bangalore Principles on the Judicial Conduct 2002 have also come to emphasize the increased significance of courts in entrenching rule law and enhancing legal reform and institutional consolidation of democracy. See particularly paragraphs 5, and 6 of the Preamble to the Bangalore Principles.

53 STRAS, David R. and RYAN W. Scott. NAVIGATING THE NEW POLITICS OF JUDICIAL APPOINTMENTS. Northwestern University Law Review 102, no. 4 fall, 2008: 1869-1917; MALLESON, Kate. and RUSSELL, Peter, H. eds. Appointing Judges in an Age of Judicial Power: Critical Perspectives from around the World. Toronto; Buffalo; London: University of Toronto Press, 2006; VOETEN, Erik. The Politics of International Judicial Appointments: Evidence from the European Court of Human Rights, International Organization 61, 2007 pp 669-701.

54 Marbury v. Madison See note 20. One should quickly add that in the Civil Law Tradition the supremacy of the courts as the determinants of constitutionalism does not have the same level of pre-eminence as in the common law tradition. I would argue that it is more 
For instance, chapter 8 of the South African Constitution 1996 provides for courts and administration of justice in general. It makes deliberate decisions to insulate the judicature and everything connected with it from the manipulative influence of other organs of government. It vested the judicial authority of the republic in the courts, guarantees their independence and subjected them only to the tenets and provisions of the constitution and the law in general. To also increase the safeguards granted to the courts and the judiciary in general, it went further to provide that "organs of state through legislative and other measure, must assist and protect the courts to ensure the independence, impartiality, dignity, accessibility and effectiveness of the courts." ${ }^{55}$

Similar provisions regarding judicial review can be found in most other modern constitutions around the globe today. What this has done is to put the idea of judicial review beyond the contestations of the old. A further expansion it is the creation of constitutional courts within the larger instrumentalities for the safeguards of rule of law and fundamental rights. Obviously a contributing factor to this is the growth in the instrumentalities for protection of human rights since the UNDH 1948. This further stretches the horizon of constitutions.

Comparatively, what is seen is also a largely two-part structure for the institution and creation of constitutional courts. These observable models are: the use of the traditional system whereby the supreme court - as it is called in most jurisdictions - plays the critical role of interpretation of constitutional matters. It is therefore the court both of general competence and the court of jurisdictional competence in all constitutional matters. This is called the unification model or centralized model. The second model often seen is the bifurcation model. Here the constitutional court is separate and has a life of its own. This seen in the South African model. We shall proceed to discuss this in the next segment beginning with the unification model.

\subsection{Unification}

Within the common law legal tradition, there is a noticeable prevalence of the unification model of constitutional courts. I use constitutional courts here in a very liberal sense the common law tradition does not essentially view the constitutional court as separate and autonomous. This is not far-fetched bearing in mind that the nature and evolution of common law which is heavily dependent

complex as the courts though significant in the legal system are often place below the parliament or the law maker. Equally as we notice with the French system, the existence of administrative tribunals which often determine the legality or otherwise of acts of organs of state are

55 Section 165 (4) South African Constitutional 1996. The constitution further created the courts and the areas and spheres of jurisdiction within the lager legal system. In doing so it elevated the Constitutional Court as the Court of finality and gave it jurisdiction to construe the most important constitutional questions in the country. See Sections 166; 167; 168; 169; and 172 of the Constitution (Supra). 
on practices and precedents. What we then have in the judicature acts of most common law-oriented traditions is a merger or integration of both powers of general judicial review and together with the powers of constitutional review. All Commonwealth Countries used to be like this.

It is important to note here that this does not represent the comprehensive picture of what happened in common law jurisdictions. Many of these jurisdictions have developed several iterations of the model. But it paints a broad canvas of the of constitutional review competence within the tradition. The United States, Nigeria, and Namibia are representative of this unification model. What we notice therefore is some sense of decentralized judicial review of the constitutional questions while the supreme court has ultimate right of determining the finality of disputes. What this means is that except where otherwise provided, the supreme court in these jurisdictions does not have original jurisdiction in disputes that call for constitutional interpretation.

Thus other courts - particularly high courts - can interpret and determine matters with constitutional questions. But there are still peculiarities from one country to another. For instance, a noticeable approach in most of these courts is what is called the empaneling of a constitutional tribunal within the same court structure. In Nigeria for instance, constitutional matters before the Supreme Court are determined by a panel of seven (7) judges, whereas in other general matters, are determined by a panel of five judges. The is different within the US Supreme Court since there is only one panel of nine (9) judges who must all sit on a matter before it. The Supreme Court of the United Kingdom also uses this structure. In Kenya the structure is also like that of Nigeria. Scholars are still deliberating as to the advantage of one form over the other. For some, having a single panel like the United States, and the United Kingdom recently encourages certainty, clarity and collegiality in decision making. Thus, the jurisprudence of the court becomes even more predictable because of the collective approach and the fact that precedents are not likely to be easily avoided since all the judges participate in the judicial deliberations that precedes judicial determination of cases. Also, there is an argument for rigor and more nuance in the diversity opinions that is elicited when all judges are exposed to the same subjects. It also makes for wider representation of views. For emerging democracies where judicial accountability and transparency is also sometimes challenged, it has been opined that common panel makes it more onerous to seek to compromise the judges as it will mean compromising all or at least a larger number of judges to secure majority votes. Thus, collectivity - one panel consisting of all the judges enhances standards and encourages judicial whistle blowing.

On the flip side, it has been argued that one panel of judges reduces access to justice because only a few cases will be heard within a given legal year. In other words, courts will be constrained to choose few cases to hear and in so doing may set procedural standard that whittles down access to justice. There is 
also a chance of having limited representation and hence the chances of judicial capture by the other organs of government is heightened when it is only one panel of say 9, or 11 persons. Thus, the politics of judicial appointment becomes intense because all that is need to gain political advantage is either five or six members of the panel. This has played out acutely in the United States. So far, South Africa and the United Kingdom has managed to avoid this politics due to the method of selection which is rather more insulated from the politics of the day. Both countries have the National Judicial Commission/Council which has powers to select and appoint judges thus circumscribing the role of the other arms of government. ${ }^{56}$

\subsection{Bifurcation}

Another model of the Constitutional Court is the bifurcated model. What this means is that there are essentially two Court systems within the judicial system. Here there is a creation of separate, specialized court called a constitutional court. It has a life of its own. It is neither antagonistic nor dependent on the other court branches. So while they belong to the same judicial system with the other branches, it is conceptually and functionally different. To further clarify, one could say that it is distinct from the courts of general competence dealing with the day to day routines of adjudication of rights, privileges and interest in society.

More so, the constitutional court in this model - bifurcation - is a permanent fixture of the judicial system. It is entrenched within the constitutional framework of the democratic state with clear modalities prescribed and protected by

56 In South Africa, the 11 judges of the Constitutional Court are independent and cannot be members of Parliament, of the government or of political parties. Sections 174 to 178 of the Constitution provides for the method of appointment of all judicial officers. Thus, the Judicial Service Commission draws up a list of candidates which must have three more names than the number of vacancies. The Commission can only shortlist after calling for nominations and calling for nominations and holding public interviews. It is only then that the President, after consultation with the Chief Justice and the leaders of political parties represented in the National Assembly, chooses the judges from this selection. These judges serve for a non-renewable term of between 12 and 15 years. See also HAZELTON, Morgan. HICKMAN, Kristin, TILLER, Emerson Panel Effects in Administrative Law: A Study of Rules, Standards, and Judicial Whistleblowing, 71 SMU L. Rev. 445, 2018. <availablehttps://scholar.smu.edu/smulr/vol71/iss2/3>; KATE, Malleson, and RUSSELL, Peter H. (eds.) Appointing Judges in an Age of Judicial Power: Critical Perspectives from around the World. Toronto; Buffalo; London: University of Toronto Press, 2006. Available http://www. jstor.org/stable/10.3138/9781442670921. The procedure in the United Kingdom is equally similar to the extent that it is governed by the United Kingdom Constitutional Reform Act 2005 (as amended by the Crimes Act 2013). Essentially, vacancies are advertised, and candidates are invited to submit a personal statement, examples of work and details of independent assessors. This is often in consultation with the Lord Chancellor, the First Minister of Scotland, the First Minister of Wales and the Judicial Appointments Commission in Northern Island and senior judges across the UK. Thereafter an interview is conducted and a report recommending persons to be appointed is submitted to the lord Chancelor. 
the constitution for the purposes of performing its critical duty of being the sentinel over the constitutional ramparts of the society. This is different from what is obtainable in the unified model. Equally it differs from what is called constitutional tribunal wherein a constitutional panel is ad hoc and constituted as the need arises within the same unified court system. In some cases these ad hoc constitutional panels are constituted by the head of the court at the application of a litigant, a body corporate, organs of state or such other public bodies as disputes arise. Constitutional courts within the context of the bifurcated model are thus sui generis.

It is of note that the independence of the Constitutional Court within this model is sometimes a source of contestation for supremacy with other courts system in the state. ${ }^{57}$ Increasingly however, transitional democracies are beginning to anticipate this tension and therefore pre-empts it via constitutional provisions or clearly set out articles in the establishment act of the constitutional court. This was clearly done in the South African court which we will highlight in a short while.

\section{Adoption of Constitutional Courts in the Southern African Region - A Comparative Analysis}

"A swallow had built her nest under the caves of a court of justice. Before her young one could fly, a serpent gliding out of hole ate them all up. When the poor bird returned to her nest and found it empty, she began a pitiable wailing. A neighbor suggested by way of comfort, that she was not the first bird who had lost her young. "true" she replied, but it is not only my little ones I mourn, but that I should have been wronged in that very place where the injured fly for justice". ${ }^{58}$

The above quoted lines reveal without more, shows that de jure proclamations of constitutional justice, do not automatically translate de facto justice. Access to justice therefore, remains a debilitating challenge, even in established democracies. All you need to confirm this is to look at the docket of any supreme court in the world to see just the number of pending cases. This is worse in authoritarian states and transitional societies.

The Southern African region is known for complex societal shifts ranging from attempted minority settler domination, and the struggle to overcome colonialism, to authoritarianism and dysfunctional justice architecture. This particularly so in the cold war era as the struggle for democratization climaxed. Thus coming on the heels of the end of the cold war a number of democratization pro-

57 LIN, Chien-Chih. \& HSU Ching-Fung. An Inter - Court Struggle for Judicial Supremacy, Penn Law: Legal Scholarship, Penn Law: Legal Scholarship Repository, 2016.

58 Aesop's Fables, Library of Congress Collection, http://www.read.gov/aesop/001.html < visited $07 / 16 / 2018>$ 
cess intensified in the region. Apartheid was ultimately deposed in South Afri$\mathrm{ca}$, and Namibia secured independence. A raft of other constitutional reforms also evolved in the region. One of such reforms that birthed in the region was the transplant/adoption of the constitutional court system. While not all of the countries adopted this model, a good number of them adopted it. Indeed amongst those that adopted it, it was adopted with different modifications and instrumentalities.

What this reveals, is that the idea of constitutional courts has been interpreted or rather translated in different senses across the region. In this work we have selected a few of these jurisdictions just to point out what is happening and possibly set an agenda for future legal research in this most important area of law. The choice of South Africa is because it presents a particularly unique experience in the region. It is a nation whose progressive constitutional democratic development since the end of apartheid, has renewed hope for many in the region in particular, and Africa in general.

Zambia may as well represent a set of other countries within the region, who though do not have as much regional clout of South Africa, are equally making concerted efforts to deepen the instrumentalities of democracy and human rights. Indeed Zambia was once seen as a symbol of stable democracy in the region. This is so unlike many of their neighbors, it had managed to avoid conflict like in Zimbabwe, Mozambique, Angola and Authoritarianism in Malawi. Namibia represents the functional alternative of the constitutional courts as we can find within the South African and Zambian judicature. They are therefore significant in illustrating the other side of the judicial review structure wherein there is a fusion of both the powers of constitutional review and judicial review of ordinary controversies within the state.

Overall, in this segment, we shall proceed by highlighting the establishment legislations of the constitutional courts in the chosen jurisdictions. It will also draw attention to jurisdictional competence and their position in overarching legal system.

\subsection{The South African Constitutional Court}

\subsubsection{Essential Background}

Axiomatically, context is important in understanding legal diffusion; be it transplant, translation or otherwise. The functionality of a proposed transplant or its potential dysfunctionality is also largely dependent on context. In that regard, the South African Constitutional Court, is the child of a long and tortuous wait and search for justice in South Africa. It was conceived to serve as a bulwark of justice in safeguarding the human rights provisions of the new South African Constitution. It was also to make a clean break from a history of state sponsored violation of the fundamental freedoms of citizens and civilized 
ethos. Indeed, it was aimed at charting a new course for legal development, and constitutional democracy in South Africa. Its emergence is directly linked to the checkered history of the country. This is so because, it is a country whose original sin was segregation and a conscious effort by the minority to disenfranchise the majority. Like other European settler community efforts around the region, the minority was inspired by the idea of segregation and the political and social disenfranchisement of the majority. This philosophy precipitated stiff resistance first from the indigenous communities and later by all people of goodwill around the world.

More so, there was an intra - European competition or rivalry. The British and Boers were for years fighting and maneuvering against each other in an effort to exclusively expropriate, exploit and dominate the land. To this effect, they fought wars of supremacy. The expropriation and exclusive exploitation of the resources of the land was also made without requisite concern for the welfare or interest of the indigenous communities. In the main, the indigenous communities were at best collateral challenges to this mission. When the rivalry wore thin - either out of war weariness or the need for peace became imperative - the British and the Boers made peace in 1902. This was subsequently followed by the Act to constitute the Union of South Africa in 1909.

Pursuant to this, the Union of South Africa was then inaugurated in $1910 .^{59}$ This elicited resistance and consequent government repression and introduction of more obnoxious laws and policies. ${ }^{60}$ These laws ${ }^{61}$ were largely founded on segregation and repression of freedoms. Some of the legislations included the Durban Land Alienation Ordinance, No. 14 of 1922; The Natal Provincial Council Ordinances of 1922 and The Prohibition of Mixed Marriages Act, Act No. 55 of 1949 - prohibiting marriage between whites and any other racial groups. ${ }^{62}$ The

59 Of course, owing to the exclusionary nature of the Union, it was not received well by the black majority population. It sparked off spirited effort at challenging the obnoxious union. Hence the coalition of black groups into different freedom groups. One of the most significant of this groups was the African National Congress - formed in 1912. The trade unions were also actively involved and hence began the struggle to upend the segregationist regime and install popular democracy. This enjoyed sympathy from many parts of the black world including in the Caribbean and Americas in general.

60 A raft of repressive and segregationist laws was enacted in South Africa between 1910 to the end of apartheid in the 1990's. It is on record that many of these law about 109 of them touching different aspects of society were used massively to the detriment of human rights and the courts were mere tools of this oppressive regime.

61 Some of the laws includes; the Mines and Works Act No. 12 of 1911 - providing for the granting of certificate of competency to skilled mining to only whites and colored's; The Black Land Act No 22 of June, 1913 which prohibited Blacks from ownership of Land Except on certain designated parts of the countryside which formed approximately $7 \%$ of the entire land space in the country. The Native Affairs Act of 1920 created the so-called nature and separate government systems for the blacks in the country.

62 The Natives (Urban Areas) Act No. 21, 1923; The Boroughs Ordinance No. 189 of 1924; The Minimum Wages Act of 1925 which provided for job reservation and promotion of white 
land Act of 1913 and many more entrenched racial superiority and segregation. Thus at the end of apartheid South Africa had hundreds of legislations which it must repeal out-rightly or amend substantially in order to make them reasonably justifiable in a democratic society.

Flowing from this background, the laws which the courts were called upon to enforce were in themselves unjust. ${ }^{63}$ Such unjust law could not by any stretch of articulation be the real foundations for substantive justice. The courts were thus implicated in the apartheid process and the violence it meant to the lives of many South Africans. Equally, due to the politics of segregation and exclusion, of the state, the judiciary was overwhelmingly populated by white men as judges and other functionaries in the administration of justice architecture. This was also the nature of the police, and other allied institutions with significant impact on justice administration in South Africa. It was therefore not surprising that during the course of the transition to democratic government and the negotiations that went with it, there was a feeling that there is a need to retool or indeed reinvent the justice administration system. This was not only limited to reforming the courts, but the police, the military, the prisons and all other instrumentalities of state coercion in South Africa. Indeed there was a need to change the structural foundations of apartheid which implicated all the organs of government.

In the course of that negotiation, there was some level of consensus that the human rights provisions which have been given premium in the new South African constitution have to be protected and insulated from the whims and caprices of state authority. There was therefore a palpable feeling that these institutions were deeply tainted by the past. The hearings of the Truth and Reconciliation commissions also exposed a number of failings and gross abuse of the institutions in apartheid South Africa. Because of the emergent background of the courts which we have highlighted and knowing the common law tradition which has significant footprint on the South African jurisprudential landscape, there was no existing constitutional court. The judiciary was also a representation of the past in terms of judicial person, judicial staff, procedures and all that mattered in the administration justice, hence the need to change it.

Hence, a decision was ultimately made to incorporate a constitutional court into the new basic law of South Africa. As Dugard put it, the court was "crafted in the shadow of a discredited legal order and judiciary, [and] the Court was designed to reflect and to promote a post-apartheid vision of South Africa found-

employment; the Immorality Amendment Act, Act No 21 of 1950, which prohibited adultery or any other forms of sexual intercourse across racial lines; Suppression of Communism Act, Act No. 44 of 1950; The Bantu Authorities Act, Act No. 68, of 1951.

63 This is a problem that is often missed by those who while wielding the powers of the state overly pay homage to law as it is written. The question which one should not lose sight of if the ends of justice is to be properly served is this: what if it is the law that is the problem? 
ed on the values of dignity, equality, non-racialism, non-sexism, the supremacy of the constitution and the rule of law. ${ }^{64}$ "

This was therefore a departure from the common law tradition and the adoption of a hybrid system of Constitutional Court as found in the continental or civil law tradition. ${ }^{65}$ From this ground was birthed the South African Constitutional Court. It sits at the precincts of an apartheid era prison in Johannesburg in an area generally called Constitutional Hill.

\subsubsection{Enabling law of the South African Constitutional Court.}

The South African Constitution 1996, sets out in its chapter I the foundational provisions of the constitution, including but not limited to the supremacy of the constitution, citizenship, national anthem and language. It proceeded in chapter two with a Bill of Rights stipulating and guaranteeing fundamental freedoms. This includes equality, rights to life, freedom from servitude, privacy, freedom

64 DUGARD, Jackie. "Court of First Instance - Towards a Pro-Poor Jurisdiction for the South African Constitutional Court." South African Journal on Human Rights, vol. 22, no. 2, 2006, pp. 261-282.

65 It is also significant to note here that; the South African legal Tradition is not strictly a common law tradition. It could be described as a pluralist legal system even before the desegregation ushered in by the new constitutional and the end of apartheid. Because of the nature of the evolution of the country, there is customary law or laws applicable only to indigenous population. There is also what is called the Roman-Dutch Law. This law was introduced in South Africa by the Dutch settlers who arrived the Cape of Good Hope in 1652. The law itself, however, has a longer and complex origin. It developed originally in the Netherlands as a product of the unique legal transplant or fusion between the Dutch laws and Roman law. Arising from this mix of Dutch law which has it Germanic origins and Roman law through the Justinian code. Its influence in Netherlands however has since diminished because of e combination of factors including but not limited to the introduction of the Napoleonic Code later on in the legal development history of the Netherland. However, before the superimposition of the Napoleonic Code on it and thus radical reform this brought in the system, the Dutch colonial officials have transmitted the law across the world in places like present day south Africa, Namibia, Lesotho, Swaziland, Botswana, and Zimbabwe. It was also introduced in different degrees in Sri Lank and Guyana. But as with most legal transplants, they have assumed their own respective lives and evolution in these places. They are seen much more today in the succession and inheritance law of the places where they were introduced. Indeed in some cases they are only applicable in the provinces where they were introduced and not in the entire country. See further, BISSCHOP, W. R. Modern Roman-Dutch Law: Sketch of its Historical Development, The Hague, Martinus Nijihoff, 1908. Bisschop describes it as "the law which the colonies of Ceylon, British Guiana and South Africa inherited from the Dutch Colonists of the $17^{\text {th }}$ and $18^{\text {th }}$ centuries. This law is a growth, a historical development, temporarily arrested in its course by politi$\mathrm{cal}$ and economic upheavals ... of Germanic origin, bred in the towns and provinces of the low countries, it was wedded to the law of the Roman Empire, which first appeared in its Justinian attire ... its development in the Netherlands may be divided into four periods, of which each possess its own characteristics. The period of the German tribes ...the Frankish period...the growth of independence of the courts of the Low Countries...the period of the republic of the United Seven Provinces...1581." 
of religion amongst others. ${ }^{66}$ To further insulate these provisions, it also created an outline of interpretive foundations. Thus, it called for the consideration of the fundamental freedom of the citizens in the interpretation ${ }^{67}$ of the constitutional provisions.

The judicature in South Africa is captured under Chapter VIII of the Constitution of the Republic of South Africa. Thus titled "Courts and Administration of Justice" this segment articulates the broad provisions governing the court system, the powers of the different courts (jurisdictional competence) and above all their ultimate position within the hierarchy of courts in the system. This is so important because of the issue of judicial precedence and hierarchy of norms and norm creating capacity of courts in any constitutional democracy. Therefore by the provisions of Sections 165 and 166 of the constitution the courts are created. ${ }^{68}$ The composition of the Constitutional Court is set out under section 167 of the Constitution. By this instant provision eight members of the court are compulsory for the proper siting of the court in any proceeding before it. Significantly too, it further provided that the Constitutional court is the Highest Court of the Republic; and may decide constitutional matters and any other matter, if the constitutional court grants leave to appeal on the grounds that the matter raises an arguable point of law of general public importance which ought to be considered by that court. ${ }^{69}$

The Constitutional Court has exclusive jurisdiction over a number of controversies. To wit: "disputes 'between organs of state in the national or provincial sphere concerning the constitutional status, powers or functions or functions of any of those organs of state; the constitutionality of any Parliamentary or Provincial Bill as in section $79^{70}$ or $121 .^{71}$ It also has powers to "decide applications as

66 Section 7 to 39 of the Constitution made far reaching provisions for the protection of the rights of citizens. It did not just do this; its uniqueness is also in its clear attempt to set the parameters for the operation for the law even in states of emergency. For instance in Section 7 (1) of the Constitution, it provided that the Bill of Rights "is a cornerstone of democracy in South Africa. It enshrines the right of the people in our country and affirms the democratic values of human dignity, equality and freedom." In Section 37 it is quite creative and progressive how the Constitution made provisions that strictly circumscribed the nature of emergency powers and how they might be used. Indeed, it created a table of non-derogable rights even in states of emergency. This includes life, equality, human dignity and slavery and servitude.

67 Section 39 " when interpreting the Bill of Rights, a court or tribunal or forum - must promote the values that underlie an open democratic society based on human dignity, equality and freedom; must consider international law; and may consider foreign law." It also called for the promotion of "the spirit, purport and objects of the bill of rights" when interpreting the Bill of Rights.

68 The Constitutional Court is established under section 166 (a).

69 Section 167 (3) (a) (b). These provisions were in line with the amendments made to the South African Constitution via Amendment No. 36128 vol. 572 of February 1, 2013.

70 Section 79 provides for Assent to Bills generally and the judicial review of same.

71 Section 80, application of members of national Assembly to Constitutional court regarding 
provided for under section $80^{72}$ or $122^{73}$ of the constitution." It also has powers to decide on the constitutionality of any amendment of the constitution. It is also within the powers of the court to decide whether the Parliament or the President has failed to fulfil a constitutional obligation; or to certify a provincial Constitution in terms of section $144^{74}$ of the Constitution. It is also the province of the Court to make the final determination regarding whether an act of Parliament, a Provincial Act or Conduct of the President is Constitutional.

Finally, it was also granted the powers to confirm any order of invalidity made by the Supreme Court of Appeal, the High Court of South Africa, or a court of similar status before such order can come into force. Since then, the constitutional court has been at the heart of every attempt to reclaim the dignity of South African citizens. It has delivered judgments on that not only enhanced the enjoyment of fundamental rights but also set the tone for legislative enactments in order to enhance a post-racial South Africa.

\subsection{The Zambian Constitutional Court ${ }^{75}$}

\subsubsection{Essential Background}

The constitutional history of Zambia is also an interesting entanglement between the forces of colonialism on the one hand; and the right and struggle of the people for self-determination, racial equality and other forms of fundamental freedoms. In post-colonial Zambia, it has also remained a continued struggle to set out clear democratic tenets that encourages accountability, respect for rule of law, removal of dictatorial accumulation of executive powers and enshrining a culture of free and fair elections. Though Zambia did not suffer the fate of South Africa as regards apartheid, it still had the same challenges as any other outpost of British Colonialism in the region. Colonialism was therefore the first foundation of legal transplant in the region as well as in the country. The imposition of the Common Law system and the consequent, inferiorization of the traditional and indigenous legal structures was therefore self-evident. This has been the subject matter of many scholarly interventions.

What is seen therefore is the ubiquitous imprint of the Westminster constitutional tradition in the country. This is traceable to the establishment of the

Constitutionality or otherwise of legislation.

72 Assent to Bills - subsidiary unit government constitutionality thereof section 121 .

73 Section 122 - Federal review of subnational legislation.

74 Section 144 - Certification of provincial constitutions.

75 GANN, L. H. The Birth of a Plural Society: The Development of Northern Rhodesia Under the British South Africa Company, 1894-1914, The Rhodes-Livingstone Institute Northern Rhodesia, Manchester University Press, 1958 ; ROBERTS, Andrew. A History of Zambia, New York, Africana Publishers Co., 1976; CHIPUNGU, Samuel. Guardians in their Time: Experiences of Zambians Under Colonial Rule, 1890-1964 London; Macmillan Education, 1992; NDULO, Muna. \& KENT, Robert. Constitutionalism in Zambia: Past, Present and Future, Journal of African Law, 40 (2), 256-278, 1996. 
British South Africa Company and the empowering of the same company led by Cecil John Rhodes as the administrator of the country in 1891 - then referred to as Northern Rhodesia. This arrangement gave Rhodes unfettered control to the country, and its exploitation. This remained so until 1923, when the British government took over the direct administration of the territory. Through series of Orders in Council, ${ }^{76}$ the British Crown determined the fate of the country through colonial administrators. In 1964, the British Crown executed another Order in Council, which granted independence to Zambia - the Zambian Independence Act 1964. While this opened a new phase in the constitutional development of the country, it did not satisfy the full aspirations of the people as an independent sovereign country and its judicature. Hence appeals from Zambia still had to go to the Judicial Committee of the Privy Council in London. There was therefore a need for an autochthonous constitution. The attempt to achieve this manifested in a number of efforts to amend the constitution in order to enable it to meet the democratic and justice administration aspirations of the country. However, it seems that, that goal has continued to elude the country with its attendant consequence on the efforts geared towards entrenching democracy in the body polity in Zambia.

In summarizing the yet to be realized democratic constitutional aspirations of the country, Muna Ndulo had this to say:

"in the last fifty years, Zambia has engaged in numerous efforts to develop a new constitution. Prior constitutions include the 1964 Independence Constitution, the 1973 Constitution and the 1991 Constitution. In addition, there has been significant constitutional amendments including those of 1969. The efforts have been directed at adopting a more democratic structure, as well as political institutions that would be less susceptible to political manipulation. At the core of the demands is a call for the development of viable institutions of the state that promote participation, transparency, accountability and devolution in governance. Excessive concentration of powers in the executive has put constitutional and institutional reforms on the national agenda". ${ }^{7}$

What is clear is that while the struggle for freedoms and popular democracy was the main issue in South Africa in the face of apartheid, Zambia on its part has had to struggle with the failure of real democratization in the aftermath of independence. First Zambia had to struggle for independence. After independence, the nation was faced with the struggle for internal democracy especially in the face of the declaration of one party system in 1973. The context of the emer-

76 Parliamentary Legislations and Pronouncements of the Queen Regarding the Governance of British Colonial territories.

77 NDULO, Muna Zambia's Unfulfilled Struggle for A New Constitution: Comments on the 2016 Constitution, Southern African Institute for Policy and Research (SAIPAR), Discussion Paper Series No 1. 2016. 
gence of the South African Constitutional Court, and that of Zambia diverges at that point. Some factors may further explain the divergence. For instance Zambia has had a longer period of independence rule and therefore presents a better platform for the assessment of the success or otherwise of popular democracy. South Africa on its part is a relatively younger popular democracy. The euphoria of post-apartheid society held sway for a reasonable time, thus, limiting the ability of the people to question the contributions of the new leadership to the quest for a truly democratic South Africa. It is notable that this is gradually shifting as the post-apartheid generation 'the born free generation' - have come of age and are presently questioning the seeming illusiveness of the promises of postapartheid South Africa as captured in the rainbow nation's constitution.

Second, while there are evident issues of identity politics in a pluralist society as in Zambia, it is largely the question of the excessive executive powers used to alienate the general populace from the benefits and promises of justice in a democratic society that is the main subject of controversy. South Africa on the other hand, has a more sharply-focused identity contestations which unwittingly sometimes insulates the African National Congress from the realities of good governance as an irreducible minimum of democratic societies. I shall return to this presently, but it is intriguing, how the communities that managed to overcome European minority domination in the early days of independence, appear to have mismanaged their independence prospects through a number of missteps including the pursuit of narrow personality cults and executive power concentration. The impact of this on public institutions like the legislature, the judiciary and indeed the entire justice administration system, I would argue, is far-reaching. The post-independence constitutions centralized powers and this is a recipe for crisis in complex societies as we often find in Africa.

It seems to me, that this is what has kept the call for constitutional amendments to devolve and decentralize powers strident within Zambia till date. The Zambian Constitution 2016 also obviously attempts to meet these yearnings. However, as can be seen in some of the cases that have come to the Zambian Constitutional Court since then, it seems the goal of accountability and judicial restraint of executive lawlessness and guaranteeing of fundamental freedoms have not been well served. The 2016 Constitutional Amendments did not create effective means of checking executive powers. From this nutshell background I will turn to the establishment and enabling powers of the Zambian Constitutional Court.

\subsubsection{Establishment and Enabling Law of the Zambian Constitutional Court}

The debate about the establishment of constitutional court ion Zambia has been on for some time and the enactment of the laws establishing it in $2016 \mathrm{did}$ not end that debate. Rather, what has happened is that it has transformed the 
nature of the debate. Thus seed of constitutional court legal transplant germinated effectively in Zambia in 2016. It is therefore a fairly new development in the country and leaves limited material for the analysis of its effectivity and functionality of this court in the judicial development of the country. It is therefore my approach here to pay particular heed to the instant provisions of the law as the nearest and best available evidence of the role the Court is playing in the legal development of the country. This is without prejudice to a few symbolic cases that I will highlight. It is also important to note that Zambia operates a unitary system of government with its attendant concentration of powers at the center. The central government therefore, dominates the legal architecture vis-à-vis the provinces. While the evident power concentration in the central executive is well documented in the country's constitutional literature, its effect on the judicial organ is quite significant though it does not enjoy as much public discourse as the other branches of government.

Of course, this is not essentially unique to the Zambian system because the idea of judicial precedent and the categorization of courts as superior and inferior courts as was done in the British Colonies, appears to have further deepened the concentration of powers at the central judiciary. In Commonwealth Africa, judicial powers are therefore often concentrated and controlled centrally with little or no devolution to the provincial courts. A few countries have adopted a federal system, but the courts are still centrally unified. ${ }^{78}$ Indeed the inferiorization' of customary law and the idea that colonial officials could not be subject to them did not help matters in the overall articulation, design, and development of the judiciaries in these countries with which Zambia shares a common heritage. Prior to 2016 therefore, the Supreme Court of Zambia was the final appellate court with jurisdiction to hear and determine all types of legal controversies whether constitutional or otherwise.

However, by Article 127 of the Constitution of Zambia (Amendment) Act No. 2. 2016, the Constitutional Court of Zambia was established. ${ }^{79}$ The amendment equally had the effect of altering, and ordering the jurisdictional capacity, constitution, and hierarchy of the courts within the Zambian justice administration system. In the words of article 127 "there is established the Constitutional Court which consists of the - the President of the Constitutional Court; and the Deputy President of the Constitution Court; and Eleven other judges or a higher number of judges as prescribed".

78 For instance in Nigeria, appeals lie from the state high courts to the Court of Appeal which has divisions in the different Zones and appeals can proceed further to the Supreme Court of Nigeria. New lawyers are admitted as barristers and solicitors of the Nigerian Supreme Court, unlike in the United States for instance where they are admitted to Practice in the New York Supreme Court.

79 The Law creating the Court was assented to by the President on January, 5, 2016. 
The Jurisdictional Competence of the Court is set-out under Article 128 as both original and final in hearing:

- Matter relating to the interpretation of the constitution;

- A matter relating to a violation or contravention of this constitution;

- A matter relating to the president, Vice President or an election of President;

- Appeals relating to election of members of parliament and councilors; and

- Whether or not a matter falls within the jurisdiction of the constitutional court.

Above all, it is also clearly provided in the Constitution that a decision of the constitutional court is not appealable to the Supreme Court of Zambia. This seems problematic on the face of it because, you cannot have two equally highest court. The court system is better as a pyramid than as two pedestals. For example in the United Kingdom, the United States, Nigeria, Kenya, and South Africa, there is a final court which is above every other court. It is therefore left to be seen the compelling state interest which necessitated the approach now adopted in the case of Zambia.

This implies two things. First, it is a court of finality and its decision no matter how perceptibly bad will enjoy the full protection of the law and presumed to be infallible until otherwise overruled by the same court. Such judicial review of past decisions by the same court cannot have retrospective effect. Second, by virtue of the finality of the decisions emanating from the Constitutional Court, it is a norm creating institution within the larger framework of the Zambian justice administration system. This becomes more interesting when the provisions of section 127 are read in conjunction with section 121. Section 121 provides that, the Supreme Court of Zambia and the newly created Constitutional Court of Zambia are of equal hierarchy. So, appeals do not lie neither from the decisions of the Supreme Court of Zambia to the Constitutional Court, nor vice-versa. There is also no mechanism or administrative institution with capacity to resolve potential frictions between the two normatively active judicial institutions.

What I see here is thus, a duality of norm making institutions within the same justice administration system. The possibility of this creating legal entanglements and institutional difficulties, I would argue, is clear and present. First, it is indicative of poor translation of the idea of constitutional courts. This is because, the contextual grounds for the adoption, adaptation or creation of an entirely new specialized court within Zambia did not seem to emanate from its immediate political and constitutional development history. It is intriguing as to the fuller justifications for this creation of an entirely new constitutional court in the face of the realities regarding devolution of powers and decentralization of Zambia's political and economic levers. The question that one is unable to effec- 
tively answer now is; whether the Zambian state acted with proper understanding of the possibility of institutional dysfunctionality that may arise from having two norm/rule creating institutions in the judicature?

Second, legal theory, seem to suggest too, that the normative character of supreme courts is also deeply entrenched in the Zambian system since it is based on the common law doctrines of hierarchy of courts and judicial precedents. supreme courts in the Common Law Tradition thus do not make sharp distinctions between constitutional issues and other issues of law. This is so because constitutional issues can become entangled with other areas of law like property rights, socioeconomic rights, criminal trail proceeding, inheritance, matrimonial causes and custody. It therefore becomes readily possible that the rules of recognition may differ between the two courts. Much as rule of proceedings or general procedural requirements can define in detail the litigation policies of the courts, it arguable that such rules though having special character, cannot override constitutional amendments where they conflict with the later. A constitutional court may be activist in its disposition and this may unduly whittle down the institutional standing of the supreme court though they had been stated as being of equal standing. It appears to me that the constitution court creating may have unwittingly set the stage for conflict of laws since questions of recognition, enforcement of judgments, procedures, and overall choice of forum and rules may become new spaces of contestations within the justice administration system. Taking it a little further into the theoretical conceptualization of normative hierarchy in a legal system; it seems that the constitutional court which has the powers of interpreting the grundnorm ${ }^{80}$ may unwittingly collide in some situations with the supreme court since it is not bound by it. It creates unnecessary ambiguity. Beyond judicial decorum, it seems that both courts can easily work at cross purposes since none has a supervisory role over the other. The bifurcation therefore, between the Supreme Court and the new Constitutional Court does not seem to be neat enough to avoid potential grounds of conflict. Of course, this is still the young age of the Constitutional Court of Zambia and its steps may grow steadier as time passes.

This is different from the position in South Africa where the Constitutional Court is declared as having the supervisory role in the system and serves as the highest court in the land. It is important to note that this position of the South African Constitution, seems to have been the major source of her strength and efforts so far to set new foundations for enforcement of fundamental freedoms, and holding the other branches of government accountable. This also eliminates the possibility of controversies which can arise due to the existence of two normative courts within the judiciary.

One other critical provision of the law creating the Zambian Constitutional Court is that; "the Constitutional Court Shall be constituted of uneven number

80 Kelsen the Pure Theory of Law (op. cit.) note 21. 
of not less than three judges, except when hearing an interlocutory matter." ${ }^{81}$ However, the full bench shall be constituted of an uneven number of not less than five judges. What this provision reveals in that, there could be more than one panel of the court. This is particularly so when construed together with the provisions of section 127 (a) (b) and (c). ${ }^{82}$ This is so because, the law provides for a maximum number of 13 judges or as may prescribed by an act of parliament. Despite providing for this number of judges it sets the full panel at five. This may offer flexibility, but it has challenges which obviates the noted flexibility and any other advantage arising therefrom.

Again, this is different from the South African model of constitutional court, because the Constitutional Court of South Africa is one panel and sits together in all matters before it. ${ }^{83} \mathrm{~A}$ number of advantages are attributed to this system whereby it is one panel instead of multiple panels that can be constituted and reconstituted in several ways. For one it seems to guarantee oneness of purpose. Since all the judges must sit to hear and determine the any matter before the constitutional court, it create a sense of collective duty and responsibility. It diminishes the chances of making the law appear to be the opinion of just a few judges of the court without more. This is very important in fragile democracies where in the courts often are called upon frequently to mitigate the undemocratic disposition of state officials which often borders on executive lawlessness.

Increasingly, the uniform panel has been seen as better since it reduces the chances of a biased assignment of cases to particular set of judges. It whittles down the powers of Chief Justices or president of courts who may have been tempted to assign particular cases - especially those of high public interest - to their cronies. While there is no intention to challenge the integrity of 'multiple empaneled' courts of finality, or their inherent capacity to render justice on matters before them, as set out in the Bangalore Principles of judicial integrity, it has become apparent that sometimes judicial powers may become subject matters of political influence or attempt thereof. A case in point is that of the Chief Judge of India in recent times. ${ }^{84}$ In developing democracies like Zambia, it seems it is

81 Section 129 Zambian Constitution Amendment Act no 2, 2016.

82 This stands to the effect that the court shall consist of the President of the Court, the Deputy President of the Court and eleven other Judges or a higher number of judges as prescribed.

83 The trend around the world seems to be shifting towards one panel of constitutional/ supreme courts. The US is known to have a single panel Supreme Court. This is also the case in the Supreme Court of the United Kingdom established in 2009.

84 In January 2018, a group of judges from the Supreme Court of India alleged that the Chief Judge of the Indian Supreme Court was in the habit of assigning "important cases selectively." They alleged that "there have been instances where cases having far-reaching consequences for the nation and the institution have been assigned by chief justice of this court selectively to the benches of their preference without any rational basis for such assignment". See The Economist, https://www.economist.com/asia/2018/01/18/judges-onindias-supreme-court-accuse-the-chief-justice-of-bias < visited> August 5, 2018. 
more worrisome and the potential for attempts to influence judicial outcome very present. This is especially so in election related issues and matters affecting the powers of the president and the exercise of same.

It is therefore obvious that while the two countries - South Africa and Zambia - have adopted the idea of constitutional courts. Both countries have done so in different ways. Obvious distinctions are found in the hierarchy, constitution and overall jurisdictional competence of the courts. What is also notable is that the transplant effect of the two courts in these separate countries differ. I shall say more on this when I examine a number of decisions that have been handed down by both courts. But before then, it is important to highlight the functional equivalents of these constitutional courts especially as we can see in Namibia and Botswana.

\section{Functional Equivalent}

It is a cardinal postulation of functional comparative law that legal systems face similar problems. That these problems are solved through different measures in different systems. It is also the theoretical claim of functionalism that despite the adoption of these differing measures, or solutions to the noted problems of the legal system, the outcomes are often the same. Now, it is debatable how much of the functional comparative method is unassailable. ${ }^{85}$

However, functional comparison has become a significant aspect of comparative legal studies. Thus when I say functional equivalent here, I mean institutions which perform the same type of roles envisaged for constitutional courts. That is to say, they perform interpretive functions and also bear the burden of creating normative orders that guarantees or otherwise derogates from the rights and freedoms of citizens in constitutional democracies. They are courts of finality and from their decisions especially on matters of constitutional significance, we can draw inference or interpret the constitutional development of the country. Equally comparisons can be made between them and those other courts which are described as constitutional courts in strictu sensu. In this dimension, Namibia and Botswana do not have constitutional courts as in the models seen in South Africa and Zambia, but they have supreme courts which perform the out the dual function of determining constitutional controversies on the one hand and the day to day legal contestations of the other. I shall use the Namibian system to highlight this functional equivalence and to show how the supreme court which

85 For some of the debates regarding the functionalist method of comparative law see: De CONINCK, Julie. The Functional Method of Comparative Law: Quo Vadis? Overcoming the mere Heuristic Aspirations of (Functional) Comparative Legal Research? An Exploration in Possibilities and Limits of Behavioral Economics: Global Jurist vol. 9. Issue 4, 2009; MICHAELS Ralf. Explanation and Interpretation in Functionalist Comparative Law - a Response to Julie de Coninck, https://scholarship.law.duke.edu/cgi/viewcontent.cgi?article $=2753 \&$ context $=$ faculty_scholarship $<$ accessed August 13, 2018> . 
has general mandate and also serves as the Court of finality in the country is able to make path breaking decisions that resonate not only the same type of jurisprudential disposition as that of the Constitutional Court of South Africa, but also shifts the needle of public policy in a significant way on otherwise frozen or largely lethargic policy spaces. Besides, the South African Constitutional Court has also rapidly evolved especially after the 2013 amendment to become structurally and functionally a supreme court.

\subsection{Namibia}

\subsubsection{Essential Background}

Namibia shares a historical umbilical cord with South Africa. The history is that of an equally unique struggle against foreign domination, genocidal repression, and apartheid colonial policy measures. It is also a relatively young democracy having achieved sovereign independence in 1990. An attempt to outline some significant aspects of that history which has influenced its constitutional development can be set out in three broad epochs. First the arrival of the Germans and the era before the World War I. The period of the League of Nations and its Mandate Status under the Union of South Africa till the World War II. Then post World War II period till Independence in 1990 and the era thereafter. While some of these categories might seem broad sweeping, it is important to remember that Namibia is one of those few countries in the world whose selfdetermination and sovereign status was the subject matter of five (5) judicial interventions by the International Court of Justice between 1949 and 1990.

Namibia therefore represents some of the ugliest episodes of colonial rule and domination in the continent. The colonial encounter between Namibia and the rampaging European powers in the late $18^{\text {th }}$ to early $19^{\text {th }}$ century became very significant when the native communities sought to resist the Germans about 1904. A lot has been written about this but the resistance by the natives proved too expensive particularly for the Herero's who were almost completely exterminated by the German Army. General Von Throter and his army spared no brutality either in killing both combatant and noncombatant natives but also in terms of the labor policies adopted against the survivors. Many were chased into the parched Omaheke and Kalahari Desert to die of hunger, starvation and dehydration. Some commentators have referred to Namibia as the test ground for the Holocaust-attempted Jewish extermination by German forces in the later part of the $20^{\text {th }}$ century.

The defeat of Germany at the end of the World War II instead of unlocking the people from the serfdom of colonialism, only became the beginning of another domination by Imperial Britain through the Union of South Africa. Of course, this was in line with the perception of the allied powers at the time that these natives have no capacity for self-governance hence they have to undergo a period of pupilage before they can be accorded autonomy or right of self- 
determination. This was a cardinal philosophy behind the establishment of the Mandate System under the League of Nations. It is interesting to see how nations which came together to fight off German occupation of their territories could feel very comfortable in suggesting such a policy for all the colonial peoples particularly those hitherto under the colonial authority of Germany. South West Africa (as Namibia was then known) was therefore designated as a mandate territory under the auspices of the League of Nations in 1919. While Russia and others were in support of the right of self-determination of the indigenous communities around the world, it will turn out that South Africa and the allies of Britain had their own proposal regarding the territory. Indeed, even at the end of the World War II, South Africa refused to accord autonomy and independence to the Namibians claiming to have assimilated it into the Union of South Africa. Hence the South West Africa cases ${ }^{86}$ before the ICJ encapsulating the struggle to actualize the independence of between 1949 and 1990. To further complicate the matters, South Africa introduced the same policies of Apartheid that it had been implementing in South Africa including segregation and forceful expropriation of lands and quarantining the natives into "homelands." These had broad negative impact on the development of rule of law and justice admiration in the country. There was as expected a resistance to the apartheid policy introduced in the territory of Namibia by the Union of South Africa whose "sacred trust" as it was stated by the League of Nations was to guide the people until they are able to stand on their own. Many of the resistance groups like the South West Africa People's Organization (SWAPO) formed in 1964 were declared as terrorist organizations. Their leaders hunted down all over the West African region. The global politics of this and the crises it generated with the intervention of Cuba in the region in support of resistance movements in Angola ultimately helped in delaying independence for Namibia. This was because the foreign policy of the United States at the time linked any independence progress in Namibia to the withdrawal of Cuba from Angola. Ironically Cuba was in Angola and not in Namibia. However, as the diminishing status of the Soviet Union showed in the horizon in the I980's talks began as to how to end the crises and usher in democratic rule by popular majority and also dismantle the instruments of segregation and discrimination via apartheid. Thus, in the course of the negotiations for independence, a number of these laws were repealed in preparation for the independence of Namibia which was achieved in 1990. But in transitional societies, it is not enough to repeal laws though that is a good start off point in reform. Structural problems can only be tackled through concerted efforts by all the institutions of state - including the judiciary. Hence, the Supreme Court of Namibia seems to bear out this eloquently in its attention to the normative and distributive impact of its decisions in the effort to transform the society. I shall use just cases to highlight this transformative disposition and the overarching

86 The South West Africa Cases, [Ethiopia v. South Africa ] ICJ Reports 1960; [Liberia V. South Africa ] ICJ Reports 1961 
impact it is having on legal development in that country - and in the region by extension.

\subsubsection{Establishment of the Namibian Supreme Court}

The Namibian Constitution 1990 has 148 broad provisions. These 148 provisions are further grouped into 12 chapters. The constitution also has 8 (eight) schedules and so far has undergone two amendments in 1998 and 2010 respectively. The administration of justice is generally captured under chapter 9 of the Constitution. Notably, its article 79 vests judicial powers in the courts which listed as - the Supreme Court of Namibia, the High Court of Namibia and the Lower Courts of Namibia. There is no designated constitution in the South African model. The Constitution accords the Supreme Court with the highest powers of judicial review and appeals to it is deemed final.

This supreme position is further given verve by the provisions of the Supreme Court Act 15 of 1990 stipulating the extent and purport of the jurisdiction of the Supreme Court. The act further provides for the tenure of judges and other ancillary provisions aimed at insulating the court and given it the requisite autonomy to function effectively. Beyond these generic provisions, it is clear that this is a fused system whereby there is no distinction between courts of ordinary jurisdiction and courts of constitutional jurisdiction. In other words the Supreme Court has the full plenitude of powers to hear and determine all forms of disputes including constitutional controversies.

Juxtaposing it side by side with the South African model one can see that these are two institutions provided with powers of judicial review to deal with controversies affecting the constitution including fundamental rights and freedoms. Effectively they have been playing that role, yet they are differently constructed. This seems to be a typical case of two not radically dissimilar societies adopting different legal instrumentalities to achieve the same goal. Thus it seems to give credence to the idea of functionalism as a comparative law methodology. Hence societies often have legal problems, and such problems may be solved by using different instrumentalities of law or relying on different institutions. Whatever may be the case there is the need to pay attention and as such find out the institution designed or better able to play that role.

\section{Some Landmark Decisions from these Constitutional Courts}

It is important at this juncture to highlight a number of constitutional cases which have made great policy and legal impact in their respective countries. The South African Constitutional Court has been quite intensely involved in making progressive decisions and judgments in the region. A number of scholars would even argue that they are over reaching executive and legislative functions in some situations. In that regard, many of the cases cited here are from that court. The choice is made based on two basic consideration. First the South Afri- 
can Constitutional Court judgments are readily accessible online and more in directly engaging issues of policy than the other courts. Second, because of the standing and public perception of the Court, its decisions have great persuasive capacity for other courts not only in the region but also in the continent at large.

\subsection{South Africa}

The State v. T. Makwanyane \& M. Mchunu CCT/3/1995. - Court Abolished Death Penalty in South Africa.

The two accused in this matter were convicted in the Witwatersrand Local Division of the Supreme Court on four counts of murder, one count of attempted murder and one count of robbery with aggravating circumstances. They were sentenced to death on each of the counts of murder and to long terms of imprisonment on the other counts. They appealed to the Appellate Division of the Supreme Court against the convictions and sentences. The Appellate Division dismissed the appeals against the convictions and concluded that the circumstances of the murders were such that the accused should receive the heaviest sentence permissible according to law - Section 277(1) (a) of the Criminal Procedure Act No. 51 of 1977 prescribes that the death penalty is a competent sentence for murder. The issue for determination was whether the sentence of death was not in conflict with the provisions of Sections 9 and 11(2) - right to life and dignity of the human person - of the South African Constitution 1993 which had then come into effect.

Whilst adopting a purposive interpretation of the Constitution and drawing inspiration from legislative history including the debates held in the course of adopting the Constitution held that the death penalty was unconstitutional. Indeed, it was the view of the Court that execution of convicts would not only be a destruction of life and dignity, but an objectification of the citizens involved since they are meant to be used as example in order to deter others. Indeed retribution was held not to be if the same value as life and dignity. Many other judgements ${ }^{87}$ of great political and legal significance have also been handed down by the Constitutional Court.

87 Equality; Minister of Home Affairs and Another v. Fourie and Another (Doctors for Life International and Others, Amicus Curiae); Lesbian and Gay Equality Project and Others v Minister of Home Affairs and Others (2005) - the common law definition of marriage and section 30(1) of the Marriage Act of 1961 declared inconsistent with the Constitution. The Court found that the failure of the common law and the Marriage Act to provide the means whereby same-sex couples can enjoy the same status, entitlements and responsibilities accorded to heterosexual couples through marriage constitutes an unjustifiable violation of their rights. In Hoffmann $v$ South African Airways - It was held that employment discrimination against an HIV-positive person was unconstitutional; In Larbi-Odam $v$ MEC in the Department of Education of the North-West Province (1997) - the court struck down regulations preventing permanent residents from holding permanent posts in the Department of Education; Equally in 1998 the Court handed down a decision decriminal- 


\subsection{Zambia}

In Malembeka (Prisons Care and Counselling Association) v. Attorney General and Another 2016/CC/0013) [2017] ZMCC 114 August 2013, (the right of persons in detention to vote was upheld).

The Zambia Constitutional Court (ZMCC) has been actively involved in settling controversies that have not only constitutional significance but also wider political and public policy implications since its establishment in 2016. Despite the age of the Court, it has managed to render a number of decisions with which its disposition can be jurisprudentially examined. Her interventions have been more pronounced in the area of elections and the rights of citizens. Some of her decisions since inception includes: Katuka v. Electoral Commission of Zambia (2016/CC/0025) (2016) ZMCC 2 (9 August, 2016); Katuka \& Law Association of Zambia v. Attorney General \& 64 others (2016/CC/0010/2016/CC/0011) [2016] ZMCC (15 August 2016). ${ }^{88}$

In the case of Malembeka (Prisons Care and Counselling Association) v. Attorney General and Another 2016/CC/0013) [2017] ZMCC 114 August 2013, the Court was faced with an application challenging the denial of the right to vote to persons in detention. In a nutshell, the petition sought the declaration and orders of the Constitutional Court upholding the rights of detainees - whether as pretrail detainees or convicts whose appeals are yet to be heard - to vote in elections. There was also a prayer in the petition seeking a broad declaration that Zambia is a progressive democracy and should therefore join the list of nations who have since upheld the right of citizens in detention to vote.

In her judgment, the Constitutional Court held that persons in lawful custody and those whose freedom of movement is restrained under a written law are entitled to vote in future elections. It also declared as void Sections 9 (1) (e)

izing same-sex relationships and marriages. This was in the case of National Coalition for Gay and Lesbian Equality $v$ Minister of Justice (1998). In the case of Bhe and Others $v$ The Magistrate, Khayelitsha and Others; Shibi v. Sithole and Others; South African Human Rights Commission and Another $v$ President of the Republic of South Africa (2004), the customary laws regarding the inheritance rights of women which was hitherto against the interest of females was declared contrary to the Constitution. It affirmed gender equality the right of African women to inherit under the African customary law of intestate succession. In the case of August $v$ Electoral Commission (1999) Prisoners were granted the right to vote. This is important if we consider that even in older democracies some states do not even allow ex-convicts to vote let alone prisoners. It has continued to intervene in areas of health care, housing and other forms of socioeconomic rights. Today the South African constitutional court is a consistent voice and reference point in terms of the judicial enforcement of socioeconomic rights.

88 Other decisions by the Court also include Hichilema and Another v. Lungu and Another (2016/CC/0031) [2016] ZMCC 5 (31 October 2016); Mulega Sata v. Given Lubinda and Others (2016/HP/EP0050) [2016] ZMCC 7 (23 November 2016); Zulu v. Daka and others ZMCC 2 (11 January, 2017); Miyanda v. Attorney General (2016/CC/0006) [2017] ZMCC 3 (9 March, 2017). 
and 47 of the Zambia Electoral Act No 35 of 2016 for contravening the provisions of Article 46 of the Zambia Constitution. It ordered the Electoral Commission to take necessary measures to ensure that eligible persons in lawful custody or whose freedom of movement is restricted by law are enabled to register and vote.

This decision and the pronouncements around it, have radically changed the law and the policy perspectives of the government in terms of the franchise of persons in detention in that country. While this may seem like meagre achievement, its significance in the legal development of Zambia is clear when one considers that until this decision, it was deemed unquestionable that detainees cannot vote, and this has been the case since independence in 1964. Equally, the problem of disenfranchisement of detainees is not peculiar to Zambia. Today even in older democracies - around the world, many countries still do not guarantee the right of detainees to exercise their right to vote. Nigeria for instance is still hoping to introduce the policy in its proposed national elections in the first quarter of 2019. The Zambian Constitutional Court is therefore in this regard playing a progressive role within the continent.

It was also interesting to see how the Court reviewed and agreed with a number of principles on the right to vote as already established in other courts of finality within the Commonwealth.

Here one can agree that while the adoption of principles of law from other jurisdictions may not be simply called legal transplant, it has some of the trappings of legal translation since it involves adopting principles from other jurisdictions and using same to interpret existing legislations and settle immediate controversies. Clearly, the courts in the region are in some sought of dialogue with each other hence allowing for the permeability of ideas from one jurisdiction to the other.

\subsection{Namibia.}

It was considered by the Supreme Court that fixed term imprisonment with no hope of parole is inhuman and violates the dignity of the Convicts. This was so held in the case of Zedikias Gaingob \& others v. The State Case Number SA 7/ 2008 \& SA 8/2008 delivered on February 6, 2018.

As noted above Namibia has also a checkered constitutional and legal history having been at the crossroad of indigenous and foreign contest for influence, control and ownership. Since independence in 1990, the country's judiciary and other institutions of state have been grappling with the tedious task of disentangling the society from a number of historical, economic and injustice entanglements and thus set it on the path to inclusive and transformative legal change. In a recent decision of the Supreme Court of Namibia the significance of a bold progressive interpretive approach to it laws and rules of criminal justice came to the fore. 
Thus in the case of Zedikias Gaingob \& others $v$. The State Case Number SA 7/ 2008 \& SA 8/2008 delivered on February 6, 2018, the appellants were sentenced to long fixed terms of imprisonment of 67 and 64 years for two counts of murder, one count of housebreaking with intent to rob and robbery with aggravating circumstances. There were also charged with two counts of housebreaking with intent to steal and theft. The chilling facts of this case were that the accused persons (Appellants before the Supreme Court) had brutally murdered their victims. The two murder victims were a couple Mr. and Mrs. Adrian, in their late seventies who were murdered on their isolated farm in the district of Okahandja. Investigations revealed that the appellants had attempted to break into the isolated farm house of the couple a few days before the fateful night. The elderly couple was alerted. Warning shots were fired, and the trio retreated to Okahandja.

They returned a few nights later when the elderly couple had already retired for the night. They then broke into the house but could not enter the bedroom where Mr. and Mrs. Adrian were asleep. The appellants provoked the dogs to bark. This stirred the couple. When Mr. Adrian sought to investigate, he was overpowered, gagged tied up and badly beaten with droppers. Mrs. Adrian was likewise savagely beaten and gagged and locked in a cupboard. They both died from the assaults. The appellants made off with money box, firearm and clothes from the house. They also broke into the farm's store and garage. A money box and some foodstuff were stolen from the store and they made off with the couple's car from the garage. They offloaded the loot at the third appellant's home which they shared and abandoned the motor vehicle in Okahandja. They were later arrested, tried and sentenced accordingly. Their sentencing created a problem because though it did not seem to make any room for parole of any kind hence the appeal to the supreme court from the lower court.

The issue in the appeal for determination was: whether inordinately fixed terms of imprisonment which could deprive an offender of the hope of release during his or her lifetime would constitute cruel, inhuman and degrading treatment or punishment in conflict with article 8 of the Namibian Constitution which entrenches the right to human dignity. It was argued on behalf of the appellants that any term of imprisonment which takes away all hope of release from an offender should be contrary to the Namibian constitution and more specifically, the inherent dignity afforded to such incarcerated offender. The litigation also revealed that this is more so because the provisions of section 115 of the Correctional Services Act of Namibia 2012 applicable to convicts in general and affecting issues of the criminal justice regarding parole does not avail the appellants since it regulates parole on persons sentenced to life. Note that by the provisions of the sections 115 and 117 of the Correctional Services Act, parole is available to persons sentenced to life imprisonment if they had served a minimum term of 25 years. What this portends is that for the appellants who were sentenced not to life by fixed terms incarceration above 25 years, the law seemed to create an ugly 
situation where parole is a hopeless expectation. The parole laws did not apply to them hence the difficulty and the need for judicial review.

The Supreme Court held that the absence of a realist hope of release for those sentenced to inordinately long terms of imprisonment would offend against the right of human dignity and protection from inhuman and degrading treatment. Furthermore, it was viewed by the Supreme Court that the sentence amounted to informal life sentences as the appellants have no realistic prospect of release in the sense of engaging in society again if at all-during their lifetimes. This is so because the appellants would only stand a chance of parole at the ages of 80 years for the first appellant, 69 and half years for the second appellant, 77 and half years for the third appellant and 66 and half years for the fourth appellant. This was held incompatible with the professed aim of rehabilitation central to the correctional services regime in the country.

From the foregoing, it was therefore, declared that the fixed term sentence which extinguishes the realistic hope of parole was not only inhuman and degrading but equally contradicts the provision of article 8 of the Namibian Constitution. I argue that this decision is as radical as they come. Its resonance and significance within the criminal justice system is better appreciated when one considers that, the court did not hesitate to intervene in such a broad policy matter. It did not-in the manner of Pilate-wash her hands off the case and claim judicial incompetence or hid under the fig leaf of deference to the other arms of government. Rather, the Court sets up the progress and agenda for further reform in the area of law. This far exceeds the judicial and jurisprudential disposition of many courts of finality around the world - especially in criminal/custodial sentencing. It appears to me that more of this progressive judicial approach is needed in order to reduce the incidence of mass incarceration which is bedeviling many criminal justice systems around the world today.

\section{Postscript}

The constitutional courts in the Southern African region have come to be the symbol of the quest for rapid transformation since the end of the apartheid in the 1990's. The historical entanglements and gaps which they appear to confront seems to me a basic factor in understanding the interpretation of rights and willing participation in the process of translating the evinced national aspirations in these countries. Indeed, they seem not to be hemmed in by the formalist traditions from which the original foundations of the judicial systems were laid. A noticeable shift in jurisprudence particularly on the rights and dignity heuristics in the region is an import contribution which they are making. However, countries like Namibia and Botswana have not adopted constitutional courts following their independence in the 1990's too. Nonetheless, their respective supreme courts - as courts of finality - have approached the duty of judicial review with a general progressive disposition. There is a noticeable cross referencing and cita- 
tion of persuasive precedents between the constitutional courts in the region and the supreme courts. What this shows is that first, different instrumentalities can achieve equally good results. Second, both courts are influencing each other in the enunciation of democratic ideals. These courts are playing critical roles in terms of policy formulation, democratic agenda setting and legal development. As the history of foreign domination continues to recede in the region and questions of inclusive economic development, land reform, mining rights and socioeconomic justice take the center stage it would be of interest to see how the courts participate in the evolution of the region. Howsoever it is, neither legal transplant nor functionalism will be able to comprehend the approach to legal development in that region. A more eclectic approach and an appreciation of local ideologies may well hold the key to meaningful comparative legal studies in the region for the foreseeable future.

\section{References}

ACKERMAN, Bruce. The Rise of World Constitutionalism, 83 Va. L. Rev. 771, 1997.

ALLAN, T.R.S. The Sovereignty of Law: Freedom, Constitution, and Common Law, Oxford, Oxford University Press, 2013.

ARONEY, Nicholas. \& KINCAID, John (eds.) Courts in Federal Countries: Federalists or Unitarists? University of Toronto Press, Toronto 2017.

BAMFORTH, Nicholas \& LEYLAND, Peter. Public Lawyer in a Multi-Layered Constitution, Hart Publishing, Oxford, 2003.

DAVIS, Michael H. A Government By Judges: An Historical Review, 35 AM. J. COMP. L. 559, 562, 1987.

DIAMOND, Larry Thinking About Hybrid Regimes, J. Dem., April 2002.

DICKSON, Brice. (ed.) Judicial Activism in Common Law Supreme Courts, Oxford University Press, Oxford, 2007.

GINSBURG, Tom. (ed.) Comparative Constitutional Design, NY, Cambridge University Press, 2012.

GINSBURG, Tom. Constitutional Courts in New Democracies: Understanding Variation in East Asia, Global Jurist Advance, Volume 2, Issue 1, 2002.

GREY Thomas, C. Judicial Review and Legal Pragmatism, 38 Wake Forest L. Rev. 473, 2003.

HIRSCHL, Ran. Towards Juristocracy: The Origins and Consequences of the New Constitutionalism Cambridge Massachusetts, Harvard University Press, 2004.

HUNTINGTON, Samuel P. The Third Wave: Democratization in the late Twentieth Century, Oklahoma; Oklahoma University Press, 1991.

JAKAB, Andras. DYEVRE, Arthur. \& ITZCOVICH, Giulo. (Eds.) Comparative Constitutional Reasoning, Cambridge, Cambridge University Press, 2017.

KLUG, Heinz. Constituting Democracy: Law, Globalism and South Africa's Political Reconstruction, Cambridge: Cambridge University Press, 2000.

KYMLICKA, Will. Multicultural Citizenship, Oxford, Clarendon Press, 1995.

LASSER, Mitchel de S.-O.-l'E. Judicial Deliberations: A Comparative Analysis of Transparency and Legitimacy, Oxford, Oxford University Press, 2009.

SCHOR, Miguel. An Essay on the Emergence of Constitutional Court: The Cases of Mexico Colombia, Indiana Journal of Global Legal Studies vol. 16 No. 1, 2008. 
ICLR, 2019, Vol. 19, No. 1.

SWEET, Alec, Stone. \& MATHEWS Jud. Proportionality Balancing and Global Constitutionalism, Yale Law School Faculty Scholarship Series, Paper No. 14, 2008.

TULLY James. Strange Multiplicity: Constitutionalism in an Age of Diversity, Cambridge, Cambridge University Press, 1995.

TURPIN, C. \& TOMKINS, A. British Government and the Constitution, Cambridge, Cambridge University Press, 2011.

TUSHNET, Mark. Red, White, Blue: A Critical Analysis of Constitutional Law, Cambridge, Massachusetts, Harvard University Press, 1988.

UNGER, Roberto. Critical Legal Studies Movement, Harvard Law Review, 563 vol. 96, 1982.

VAN DER SCHYFF, Gerhard. Constitutionalism in the Netherlands and South Africa: A Comparative Study, Nijmegen, Netherlands: Wolf Legal Publishers, 2008. 